\title{
DNA methylation and methyl-CpG binding proteins: developmental requirements and function
}

\author{
Ozren Bogdanović • Gert Jan C. Veenstra
}

Received: 7 April 2009/Revised: 19 May 2009/Accepted: 27 May 2009/Published online: 9 June 2009

(C) The Author(s) 2009. This article is published with open access at Springerlink.com

\begin{abstract}
DNA methylation is a major epigenetic modification in the genomes of higher eukaryotes. In vertebrates, DNA methylation occurs predominantly on the $\mathrm{CpG}$ dinucleotide, and approximately $60 \%$ to $90 \%$ of these dinucleotides are modified. Distinct DNA methylation patterns, which can vary between different tissues and developmental stages, exist on specific loci. Sites of DNA methylation are occupied by various proteins, including methyl-CpG binding domain (MBD) proteins which recruit the enzymatic machinery to establish silent chromatin. Mutations in the MBD family member MeCP2 are the cause of Rett syndrome, a severe neurodevelopmental disorder, whereas other MBDs are known to bind sites of hypermethylation in human cancer cell lines. Here, we review the advances in our understanding of the function of DNA methylation, DNA methyltransferases, and methyl-CpG binding proteins in vertebrate embryonic development. MBDs function in transcriptional repression and long-range interactions in chromatin and also appear to play a role in genomic stability, neural signaling, and transcriptional activation. DNA methylation makes an essential and versatile epigenetic contribution to genome integrity and function.
\end{abstract}

Communicated by E. Nigg

O. Bogdanović · G. J. C. Veenstra $(\bowtie)$

Department of Molecular Biology, Faculty of Science,

Nijmegen Centre for Molecular Life Sciences,

Radboud University Nijmegen,

Nijmegen, The Netherlands

e-mail: g.veenstra@ncmls.ru.nl

\section{Introduction}

DNA methylation is a covalent modification of DNA catalyzed by DNA methyltransferase enzymes (DNMTs). In vertebrate genomes, the addition of a methyl group occurs exclusively on the cytosine within CG dinucleotides (referred to as $\mathrm{CpG}$ ), with $60-90 \%$ of all the CpGs methylated in mammals (Bird 1986). The exceptions are CpG islands, $\mathrm{CpG}$-enriched sequences that frequently coincide with gene promoter regions and generally are unmethylated. DNA methylation in higher eukaryotes is usually associated with a repressed chromatin environment, while in the prokaryote kingdom both cytosine and adenine methylation have been described as a part of the host restriction system (Wilson and Murray 1991). Proper DNA methylation is a prerequisite for normal development and is involved in various processes such as gene repression, imprinting, $\mathrm{X}$-chromosome inactivation, suppression of repetitive genomic elements, and carcinogenesis (Bird 2002). Sites of DNA methylation recruit methyl-CpG binding domain proteins (MBDs) and several structurally unrelated methyl-CpG binding zinc-finger proteins of the Kaiso family (Kaiso/ZBTB33, ZBTB4 and ZBTB38, cf. Fig. 1). These proteins generally are thought to associate with histone deacetylase activity and establish silent chromatin (Table 1). Here, we review the recent developments in the field of DNA methylation-dependent silencing with special emphasis on the role of MBDs in vertebrate development. DNA methylation, MBDs, and their roles in disease have been more extensively reviewed elsewhere (Clouaire and Stancheva 2008; Hendrich and Tweedie 2003; Klose and Bird 2006; Lopez-Serra and Esteller 2008). 


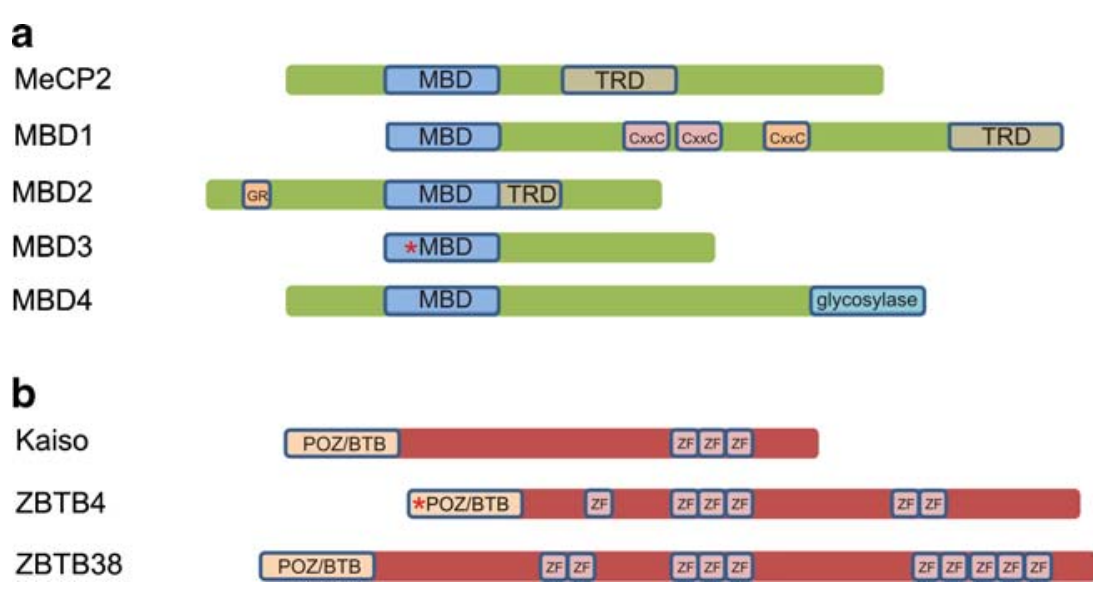

Fig. 1 Two families of proteins that bind methylated DNA. a Methyl$\mathrm{CpG}$ binding proteins $(M B D s)$ : MBD proteins display homology within their MBD domains, while the transcription repression domains (TRD) described for MeCP2, MBD1, and MBD2 are nonhomologous. In addition to its MBD domain, MBD1 is able to bind unmethylated DNA via its third CxxC zinc-finger motif. MBD2 features a characteristic stretch of glycine and arginine residues $(G R)$ and has juxtaposed MBD and TRD domains. MBD3 is, due to a

\section{DNA methylation: distribution and dynamics}

DNA methylation in different species

Vertebrate genomes are highly methylated, but many invertebrates have a low genomic DNA methylation content and a few species like Caenorhabditis elegans and Drosophila melanogaster appear (virtually) methylation-free (Tweedie et al. 1997). Likewise, both Schizosaccharomyces pombe and Saccharomyces cerevisiae are devoid of DNA methylation (Antequera et al. 1984; Proffitt et al. 1984), but the filamentous fungus Neurospora crassa utilizes a silencing pathway in which the establishment of DNA methylation is dependent on the H3K9 histone-methyltransferase dim-5 (Tamaru and Selker 2001). A study mapping DNA methylation in the Neurospora genome revealed that most of the methylated sequences correspond to transposon relics (Selker et al. 2003), in line with a role for DNA methylation in preventing the reactivation of parasitic genomic sequences in eukaryotes (Bestor and Tycko 1996; Yoder et al. 1997). Species such as D. melanogaster which have very little DNA methylation display a relatively high mutation rate due to the vulnerability of their genome to genomic transposition (Yoder et al. 1997). Although the DNA methylation mark does not seem to be particularly abundant in Drosophila, two potential DNA methyltransferase genes have been discovered (Hung et al. 1999). In contrast to the vertebrate DNMT2, which has mostly been associated with RNA methyltransferase activity (Goll et al. 2006; Rai et al. 2007), deletion of Dnmt2 from the fly genome resulted in mutation in the MBD domain, not able to bind methylated $\mathrm{CpGs}$ in mammals. MBD4, a thymine glycosylase, contains a C-terminal glycosylase domain used for excision-based DNA repair. b Kaiso protein family: three members of the Kaiso protein family have been described so far. Kaiso, ZBTB4, and ZBTB38 share a triple zincfinger domain and a BTB/POZ domain which in case of ZBTB4 contains a 60 amino acid insertion. Furthermore, ZBTB4 and ZBTB38 contain respectively three and seven additional zinc-fingers

abolishment of DNA methylation whereas its overexpression induced hypermethylation on $\mathrm{CpT}$ and $\mathrm{CpA}$ dinucleotides (Kunert et al. 2003). A single functional homolog of the mammalian MBD2 and MBD3 proteins has also been discovered in Drosophila (Roder et al. 2000). GST pulldowns as well as yeast two-hybrid assays showed that fly MBD2/3 protein interacts with the Mi-2/NuRD complex via the p55 and Mi-2 subunits (Marhold et al. 2004a). The generation of the MBD2/3 mutant allele resulted in viable and fertile flies which however showed some displacement of Mi-2 from genomic loci (Marhold et al. 2004b). Bandshifts using MBD2/3 and its mammalian MBD2 homolog demonstrated that fly $\mathrm{MBD} 2 / 3$ interacts with $\mathrm{CpT} / \mathrm{A}$ methylated, but not $\mathrm{CpG}$-methylated oligonucleotides, while the mammalian MBD2 interacted only with the $\mathrm{CpG}$ methylated probes. Also, immunohistochemistry experiments suggest that embryos treated with the DNA methylation inhibitor 5-azacytidine display a loss of MBD2/3 foci which normally overlap with the DNA staining (Marhold et al. 2004b). Collectively, these data indicate that Drosophila MBD2/3 might be functionally more similar to MBD2 than to MBD3. However, further experiments will be needed in order to determine whether MBD2/3 targets the Mi-2/NuRD complex to the sites of $\mathrm{CpT} / \mathrm{A}$ methylation or if such a complex is mainly targeted by protein-protein interactions. It is possible that DNA methylation only plays an auxiliary role, for example, during development; the 5-methylcytosine content of the Drosophila genome as assessed by liquid chromatography showed the highest signal in the early embryo (Lyko et al. 2000). While the Drosophila genome 
Table 1 Biochemical interactions of methyl $\mathrm{CpG}$ binding proteins

\begin{tabular}{|c|c|c|c|}
\hline Protein & Interacting partner & Effects of the interaction & Reference \\
\hline \multirow[t]{12}{*}{$\mathrm{MeCP} 2$} & Sin $3 A$, HDACs & Transcriptional repression & Jones et al. (1998), Nan et al. (1998) \\
\hline & c-ski, N-CoR & Transcriptional repression & Kokura et al. (2001) \\
\hline & HMGB1 & Unknown & Dintilhac and Bernues (2002) \\
\hline & $\operatorname{Sin} 3 \mathrm{~B}, \mathrm{HDAC} 2$ & Transcriptional repression & Rietveld et al. (2002) \\
\hline & Dnmt1 & $\begin{array}{l}\text { Targeting of maintenance } \\
\text { DNA methylation? }\end{array}$ & Kimura and Shiota (2003) \\
\hline & H3K9 methyltransferase & Transcriptional repression & Fuks et al. (2003b) \\
\hline & CoREST complex & Repression of neural genes & Ballas et al. (2005), Lunyak et al. (2002) \\
\hline & Brm (SWI/SNF complex) & Transcriptional repression & $\begin{array}{l}\text { Harikrishnan et al. (2005), } \\
\text { Hu et al. (2006) }\end{array}$ \\
\hline & YB-1 & Alternative splicing & Young et al. (2005) \\
\hline & ATRX & $\begin{array}{l}\text { Epigenetic regulation required } \\
\text { for neural development }\end{array}$ & Nan et al. (2007) \\
\hline & HP1 & $\begin{array}{l}\text { Transcriptional repression during } \\
\text { myogenic differentiation }\end{array}$ & Agarwal et al. (2007) \\
\hline & CREB1 & Transcriptional activation & Chahrour et al. (2008) \\
\hline \multirow[t]{4}{*}{ MBD1 } & MPG & DNA repair & Watanabe et al. (2003) \\
\hline & Suv39h1-HP1 & Transcriptional repression & Fujita et al. (2003) \\
\hline & MCAF1, MCAF2, SETDB1, CAF-1 p150 & $\begin{array}{l}\text { Transcriptional repression, } \\
\text { inheritance of epigenetic states }\end{array}$ & $\begin{array}{l}\text { Ichimura et al. (2005), Reese et al. (2003), } \\
\text { Sarraf and Stancheva (2004) }\end{array}$ \\
\hline & PML-RAR $\alpha$, HDAC3 & PML-RAR $\alpha$-mediated silencing & Villa et al. (2006) \\
\hline \multirow[t]{7}{*}{ MBD2 } & $\begin{array}{l}\text { Mi-2, MTA1-3, P66 } \alpha / \beta, \text { HDAC1/2, } \\
\text { RbAp46/48, DOC-1, PRMT5, MEP50 } \\
\text { (NuRD complex) }\end{array}$ & Transcriptional repression & $\begin{array}{l}\text { Brackertz et al. (2002), Le Guezennec } \\
\text { et al. (2006), Zhang et al. (1999) }\end{array}$ \\
\hline & $\operatorname{Sin} 3 \mathrm{~A}$ & Transcriptional repression & Boeke et al. (2000) \\
\hline & Tax & Transcriptional activation & Ego et al. (2005) \\
\hline & TACC3, HATs, pCAF & Transcriptional activation & Angrisano et al. (2006) \\
\hline & GCNF & Oct-4 silencing & Gu et al. (2006) \\
\hline & Dnmt1 & $\begin{array}{l}\text { Targeting of maintenance } \\
\text { DNA methylation? }\end{array}$ & Tatematsu et al. (2000) \\
\hline & RFP & $\begin{array}{l}\text { Enhancement of transcriptional } \\
\text { repression }\end{array}$ & Fukushige et al. (2006) \\
\hline \multirow[t]{3}{*}{ MBD3 } & $\begin{array}{l}\text { Mi-2, MTA1-3, P66 } \alpha / \beta, \text { HDAC1/2, } \\
\text { RbAp46/48, DOC-1 (NuRD complex) }\end{array}$ & Transcriptional repression & $\begin{array}{l}\text { Le Guezennec et al. (2006), Wade et al. } \\
\text { (1999), Zhang et al. (1999) }\end{array}$ \\
\hline & Dnmt1 & $\begin{array}{l}\text { Targeting of maintenance } \\
\text { DNA methylation? }\end{array}$ & Tatematsu et al. (2000) \\
\hline & CDK2AP1, GCNF & Oct-4 silencing & Deshpande et al. (2009), Gu et al. (2006) \\
\hline \multirow[t]{4}{*}{ MBD4 } & Sin $3 A$, HDAC1 & Transcriptional repression & Kondo et al. (2005) \\
\hline & FADD & Genome surveillance/apoptosis? & Screaton et al. (2003) \\
\hline & MLH1 & DNA repair & Bellacosa et al. (1999) \\
\hline & RFP & $\begin{array}{l}\text { Enhancement of transcriptional } \\
\text { repression }\end{array}$ & Fukushige et al. (2006) \\
\hline \multirow[t]{3}{*}{ Kaiso } & Tcf3 & Suppression of Wnt signaling & Ruzov et al. (2009) \\
\hline & p120 & Wnt signaling? & $\begin{array}{l}\text { Daniel and Reynolds (1999), Prokhortchouk } \\
\text { et al. (2001) }\end{array}$ \\
\hline & $\mathrm{N}-\mathrm{CoR}$ & Transcriptional repression & Yoon et al. (2003) \\
\hline
\end{tabular}

appears to be largely depleted of DNA methylation, other insect species such as the cabbage moth Mamestra brassicae, the peach potato aphid Myzus persicae, and the mealy bug Planococcus citri seem to utilize DNA methylation (Field et al. 2004). Also, significant amounts of DNA methylation along with a MBD2/3 homolog have been identified in the silkworm moth Bombyx mori (Patel and Gopinathan 1987; Uno et al. 2005). A functional DNA methylation system containing both Dnmt1 and Dnmt3 as well as a functional ortholog of the mammalian MBD family has been described in the honeybee, Apis melifera (Wang et al. 2006). In the honeybee, DNA methylation plays an 
important role in the organization of social structures as well as labor division (Kucharski et al. 2008). In bee communities, young worker bees feed a privileged subset of larvae with a substance called royal jelly (Schmitzova et al. 1998). Larvae nurtured with royal jelly develop into queens, while other bees of the same clonal origin become worker bees (Barchuk et al. 2007; Colhoun and Smith 1960). The larvae treated with small interfering RNA targeting a de novo DNA methyltransferase, Dnmt3, developed into queens with fully functional ovaries, while a control RNA did not induce that effect (Kucharski et al. 2008). This finding highlights the function of DNA methylation in phenotypic plasticity and also shows an elegant way of how epigenomes respond to environmental signals in order to determine different developmental fates. Vertebrates such as Xenopus laevis and zebrafish, Danio rerio, are known to have a high content of genomic DNA methylation as well as functional DNMTs and MBDs (McGowan and Martin 1997; Rai et al. 2006; Stancheva and Meehan 2000; Veenstra and Wolffe 2001). DNA methylation is also employed in mammal-specific ways. A phenomenon observed in both eutherians and marsupials is parental imprinting, which is allele-specific gene expression in which the expression status of an allele is determined by its parental origin (Reik et al. 2001; Wood and Oakey 2006). The differential expression status of maternal and paternal alleles is controlled by DNA methylation. Defects in imprinting are related with severe diseases such as the Beckwith-Wiedemann, Prader-Willi, and Angelman syndromes and various types of cancer (Bittel and Butler 2005; Lalande and Calciano 2007; Rainier et al. 1993; Weksberg et al. 2003). The imprints are established already during gametogenesis (Bourc'his et al. 2001; Delaval and Feil 2004). Developmental dynamics of DNA methylation and its function in vertebrates will be discussed in more detail below.

DNA methyltransferases in embryonic development

The DNA methylation mark in vertebrates is set by three DNMT family members: DNMT1, DNMT3a, and DNMT3b. DNMT3a and DNMT3b fall in the group of de novo methyltransferases, enzymes that are able to methylate previously unmethylated $\mathrm{CpG}$ sequences, while DNMT1 functions as a maintenance methylase, copying the preexisting methylation marks onto the new strand during replication (Jeltsch 2006). Although generally thought of as a maintenance methylase, DNMT1 has also been shown to function as a de novo DNA methyltransferase (Fatemi et al. 2002; Gowher et al. 2005; Liang et al. 2002; Pradhan et al. 1999). In addition, two non-canonical family members, DNMT2 and DNMT3L, have been discovered (Aapola et al. 2000; Okano et al. 1998). Various functional studies demonstrated the importance of DNMTs for early verte- brate development ( $\mathrm{Li}$ et al. 1992; Okano et al. 1999; Stancheva et al. 2001).

The DNMT1 gene was targeted in embryonic stem (ES) cells and in mouse embryos (Li et al. 1992). Both affected ES cells and embryos showed significantly reduced levels of DNA methylation. The loss of DNMT1 proved to be lethal with the majority of embryos not passing midgestation, although the ES cells remained viable and proliferative (Li et al. 1992). Dnmt1o, a variant transcribed from an oocyte-specific promoter, expressed in oocytes and preimplantation embryos, is required for zygotic maintenance of imprinting (Howell et al. 2001). In X. laevis embryos, the genome of DNMT1-depleted embryos was hypomethylated and the embryos displayed a premature expression pattern of several mesodermal markers. (Stancheva and Meehan 2000). This also led to p53-induced apoptosis and embryonic lethality (Stancheva et al. 2001). Similar observations have been made on cultured fibroblasts derived from conditional DNMT1 mouse knockouts that undergo p53-dependent programmed cell death (Jackson-Grusby et al. 2001). The DNMT1-depleted fibroblasts showed a reactivation of placental and germ line markers pointing out the role of DNMT1 for tissue-specific gene expression and embryonic development. The DNMT1 knockdown in zebrafish (Rai et al. 2006) appears to recapitulate the effects observed in mice and Xenopus with $\sim 40 \%$ of the embryos dying upon DNMT1 depletion. An interesting finding was that the response to DNMT1 deficiency was largely organspecific. One of the most affected organs was the gut, where the reduced intestinal differentiation was accompanied by the loss of expression of fabp2, a marker of terminally differentiated epithelial cells. Although markers of eye development such as ot $x-2$ and otx-5 appeared to be expressed at similar levels in both control embryos and DNMT1 morphants, histological evidence suggested a severe disorganization of retinal structures. This study emphasizes the importance of DNMT1 for tissue-specific gene expression and development. DNMT1 has been reported to interact with methyl-CpG binding proteins as well as with HDACs and histone methyltransferases to repress transcription (Fuks et al. 2003a; Kimura and Shiota 2003; Tatematsu et al. 2000). In addition, DNMT1 has been found to interact with the $\mathrm{Rb}$ tumor suppressor protein to repress transcription from promoters containing E2F binding sites (Robertson et al. 2000), linking DNMT1 to a growth regulatory pathway that frequently is disrupted in cancer.

DNMT2 is the best conserved methyltransferase although its exact function remains a topic of debate. DNMT2 appears to be dispensable for de novo DNA methylation in mouse ES cells (Okano et al. 1998), while in vitro experiments detected only a weak methyltransferase activity (Hermann et al. 2003). Interestingly, a recent study 
found that DNMT2 can function as a tRNA methyltransferase that specifically methylates cytosine 38 in the anticodon loop (Goll et al. 2006). Although the exact function of this cytoplasmic methylation event remains unclear, another study described the requirement for DNMT2 cytoplasmic activity in early zebrafish development (Rai et al. 2007). The DNMT2 knockdown was not lethal; however DNMT2 morphant embryos displayed a range of developmental defects including brain and retina abnormalities. DNMT2 isolated from zebrafish was able to methylate an RNA species of $\sim 80 \mathrm{bp}$, which by size might correspond to transfer RNA (tRNA). It is not known how many RNA species can be methylated by cytoplasmic DNMT2.

DNMT3a and DNMT3b targeting in mice revealed that both de novo DNA methyltransferases are essential for early mouse development (Okano et al. 1999). Although the expression patterns of DNMT3a and DNMT3b are largely overlapping, the functions that they carry out do not seem to be completely redundant since both knockouts turned out to be lethal. DNMT3a-depleted mice appeared normal after birth but died at 4 weeks of age. On the other hand, no DNMT3b knockouts were recovered at birth. The double knockout induced a more severe phenotype since the affected embryos showed developmental defects at E8.5 and died shortly after gastrulation. Furthermore, both DNMT3a and DNMT3b proved to be essential for the lineage-specific DNA methylation of Rhox6 and Rhox9 cluster genes, with DNMT3b contributing slightly more to the amount of methylation established (Oda et al. 2006). Taken together, these data indicate that some but not all of the functions are shared by both enzymes. This finds further support in the fact that mutations in DNMT3b, but not DNMT3a, cause a recessive autosomal disorder called immunodeficiency, centromeric instability, and facial abnormalities (ICF) syndrome. ICF syndrome is associated with hypomethylation of satellites II and III which results in expansion of juxtacentromeric heterochromatin and formation of complex multiradiate chromosomes (Xu et al. 1999). Besides the DNMT3a and DNMT3b methyltransferases, another family member has been described in the last couple of years. DNMT3L is a catalytically inactive DNMT which is known to associate with both DNMT3a and DNMT3b to establish regions of maternal imprinting (Hata et al. 2002). Furthermore, DNMT3L is able to recruit histone deacetylases through its PHD zinc-finger-like motif and possibly directs repression onto newly established imprints (Aapola et al. 2002; Deplus et al. 2002).

Dynamic changes in DNA methylation during vertebrate development

Although stable and inheritable in somatic cells, global DNA methylation patterns are dynamic during the mam- malian life cycle. Global remodeling of DNA methylation occurs twice in mammals, during gametogenesis and preimplantation development (Morgan et al. 2005). The first erasure of DNA methylation marks takes place during gametogenesis, when also the imprinted marks are reset. This involves a wave of remethylation which is needed to establish the parental imprints. The second demethylation event takes place during preimplantation development and does not affect imprinted regions (Mann and Bartolomei 2002). When compared to the oocyte genome, the sperm genome is highly methylated, which correlates well with its inactive chromatin state and compact structure (Morgan et al. 2005). Immunohistochemistry and bisulfate conversion experiments in mice showed that the male pronucleus gets rapidly demethylated shortly after fertilization (Mayer et al. 2000; Oswald et al. 2000), while the maternal genome displays a slow but progressive drop in DNA methylation levels consistent with passive demethylation. Later during implantation, the global DNA methylation levels of both the paternal and the maternal contributions to the genome increase (Meehan 2003). Such developmental changes in the DNA methylation content of the embryo have been described in other placental mammals as well (Dean et al. 2001). By contrast, the Xenopus paternal genome does not get actively demethylated after fertilization despite the occurring changes in the chromatin structure (Stancheva et al. 2002). Moreover, the global DNA methylation content as well as DNA methylation of specific loci remains high and unchanged during embryogenesis from early blastula stages onwards (Veenstra and Wolffe 2001). However, some DNA methylation remodeling has been reported for a number of developmentally regulated promoters (Stancheva et al. 2002). Likewise, southern blotting of repetitive DNA and bisulfate sequencing of single copy genes demonstrated the absence of global demethylation in zebrafish embryonic development (Macleod et al. 1999). Immunohistochemistry experiments with an anti-5-methylcytosine antibody, however, showed a reduction in signal to almost undetectable levels $1.5-2 \mathrm{~h}$ post fertilization (hpf) and a reappearance at $2.5 \mathrm{hpf}$ (MacKay et al. 2007). Possible explanations for this discrepancy include (subtle) differences in the stages and sequences analyzed and methodological differences in detection of DNA methylation. A demethylase activity involving an AID deaminase, MBD4 glycosylase, and Gadd45a has recently been reported in late gastrula to segmentation stage (8-13 hpf) zebrafish embryos (Rai et al. 2008). Gadd45a has been associated with demethylation events (Barreto et al. 2007; Schmitz et al. 2009). However, Gadd45a knockout in mice did not result in global or sitespecific hypermethylation (Engel et al. 2009) and the role of Gadd45a in demethylation is disputed (Jin et al. 2008). An equally controversial DNA demethylase function has been proposed for the MBD2 and MBD3 proteins 
(Bhattacharya et al. 1999; Boeke et al. 2000; Brown et al. 2008; Detich et al. 2002; Hendrich et al. 2001; $\mathrm{Ng}$ et al. 1999; Wade et al. 1999; Wolffe et al. 1999). To what extent the observations concerning active demethylation can be reconciled, and how DNA methylation and demethylation are targeted or regulated, and what the physiological role of DNA demethylation is in vertebrate development, are issues that await further clarification.

DNA methylation and histone modifications provide a link between chromatin and tissue-specific transcriptional programs (Kiefer 2007; Lunyak et al. 2004; Palacios and Puri 2006; Rupp et al. 2002). Until recently, most of the DNA methylation studies have been performed on individual genomic loci. However, new high-throughput technologies have allowed us to investigate thousands of $\mathrm{CpG}$ methylation sites across the genome and collect tissuespecific as well as age- and sex-dependent DNA methylation signatures. A bisulfate conversion approach combined with BeadArray technology identified DNA methylation epigenotypes specific for distinct cell populations (Bibikova et al. 2006a; Bibikova et al. 2006b). Out of 1,536 CpG sites selected from 5' regulatory regions of 371 genes, 49 sites from 40 genes were identified as potential DNA methylation markers. The differential DNA methylation patterns observed on those sites were sufficient to discriminate between human ES cells, differentiated cells, somatic cells, and cancer cells. Another study using bisulfate DNA sequencing of chromosomes 6, 20 and 22 on samples derived from 12 different healthy tissues, including fetal liver and fetal skeletal muscle, identified a number of genes carrying DNA methylation patterns specific to fetal tissues (Eckhardt et al. 2006), while a relatively new technique which uses the combination of methylated DNA immunoprecipitation (MeDIP) and microarray hybridization proved to be quite efficient in generating global DNA methylation data and assessing the differences between normal and transformed cells (Weber et al. 2005). When compared to primary fibroblasts and normal colon mucosa, the SW48 colon carcinoma cell line was found to be hypermethylated at $\sim 200$ unique genes. The same study also revealed hypomethylation of the inactive $\mathrm{X}$ chromosome when compared to its active counterpart while hypermethylation was detectable only on a subset of gene-rich regions (Weber et al. 2005). "Next generation" sequencing tools combined with methylation-specific enzyme digestion also found their application in global DNA methylation profiling (Brunner et al. 2009). The study revealed minimal, although significant, changes in DNA methylation content during human liver differentiation. While the in vivo fetal liver development was characterized by a slight decrease in DNA methylation, the in vitro differentiation of human ES cells was marked by both de novo methylation and demethylation events (Brunner et al. 2009). In conclusion, distinct DNA methylation patterns exist on specific genomic loci, depending on lineage and differentiation potential.

\section{Methyl-CpG binding proteins and embryonic development}

Generally, two different mechanisms by which DNA methylation represses gene expression have been identified. A first, direct mechanism is based on the alteration of transcription factor binding sites by DNA methylation. A methylated target sequence can interfere with the binding of transcription factors such as E2F or CREB, thereby preventing transcriptional activation (Campanero et al. 2000; Iguchi-Ariga and Schaffner 1989). A more elaborate mechanism features recruitment of methyl-CpG binding proteins which associate with various chromatin modifiers to establish a repressive chromatin environment (Fuks et al. 2003b; Jones et al. 1998; Nan et al. 1998; Wade et al. 1999; Zhang et al. 1999). These proteins read and interpret the epigenetic signals and provide a connection between DNA methylation and chromatin modification. In this section, we will review proteins that feature a MBD and the structurally unrelated zinc-finger proteins sharing a BTB/POZ domain that are known to bind methylated DNA (Fig. 1). The MBD family proteins have been comprehensively studied through the years and their characterization unraveled specific functions carried out by each family member (see also Tables 1 and 2). Mutations in the MBD family founder, methyl-CpG binding protein 2 (MeCP2), are the cause of the Rett syndrome (RTT), an X-linked neurodevelopmental disorder (Amir et al. 1999). Other MBD family proteins have been shown to bind aberrantly hypermethylated promoters in various human cancer cell lines (Ballestar et al. 2003). The MBD was initially identified as the minimal part of the MeCP2 protein required to bind methylated DNA (Nan et al. 1993), and homology searches with the MeCP2 MBD amino acid sequence led to the discovery of four additional proteins, MBD1, MBD2, MBD3, and MBD4 (Hendrich and Bird 1998). A non-conserved transcription repression domain has been identified in MeCP2, MBD1, and MBD2 (Fig. 1). Apart from its MBD domain, MBD1 protein can bind DNA via its $\mathrm{CxxC} 3$ zincfinger domain (Jorgensen et al. 2004), which shows noticeable sequence resemblance with the $\mathrm{CxxC}$ domains of DNMT1 (Pradhan et al. 2008). All MBD proteins preferentially bind methylated rather than unmethylated DNA, except mammalian MBD3 (Saito and Ishikawa 2002) and the long form of the amphibian MBD3 (MBD3 $\mathrm{LF}$ ), which due to an insertion in the MBD, is not able to specifically recognize DNA methylation (Wade et al. 1999). Generally, the affinity of MBD proteins for methylated 
Table 2 Phenotypes caused by loss of function of methyl-CpG binding proteins

\begin{tabular}{|c|c|c|c|c|}
\hline Protein & Model system & Experimental approach & Phenotype & Reference \\
\hline \multirow[t]{2}{*}{ MeCP2 } & Mus musculus & Knockout & Neural, RTT-like phenotype & Guy et al. (2001) \\
\hline & Xenopus laevis & Antisense knockdown & Improper neural patterning, embryonically lethal & Stancheva et al. (2003) \\
\hline MBD1 & Mus musculus & Knockout & Minor neural defects, increased genomic instability & Zhao et al. (2003) \\
\hline MBD2 & Mus musculus & Knockout & $\begin{array}{l}\text { Mild maternal phenotype, abnormal differentiation, } \\
\text { reduced tumorigenesis }\end{array}$ & $\begin{array}{l}\text { Hendrich et al. (2001), } \\
\text { Sansom et al. (2003) }\end{array}$ \\
\hline \multirow[t]{2}{*}{ MBD3 } & Mus musculus & Knockout & $\begin{array}{l}\text { Failure in differentiation of pluripotent cells } \\
\text { embryonically lethal }\end{array}$ & $\begin{array}{l}\text { Hendrich et al. (2001), } \\
\text { Kaji et al. (2007) }\end{array}$ \\
\hline & Xenopus laevis & Antisense knockdown & Defective eye formation, embryonically lethal & Iwano et al. (2004) \\
\hline MBD4 & Mus musculus & Knockout & No apparent phenotype, increased mutation rate & $\begin{array}{l}\text { Millar et al. (2002), } \\
\text { Wong et al. (2002) }\end{array}$ \\
\hline \multirow[t]{2}{*}{ Kaiso } & Mus musculus & Knockout & No apparent phenotype, reduced tumorigenesis & Prokhortchouk et al. (2006) \\
\hline & Xenopus laevis & Antisense knockdown & Premature activation of zygotic transcription & Ruzov et al. (2004) \\
\hline
\end{tabular}

DNA is three- to tenfold higher than for unmethylated DNA and may as well depend on the sequence context (Fraga et al. 2003). Experiments involving in vitro binding site selection revealed a requirement of human $\mathrm{MeCP} 2$ for an $\mathrm{A} / \mathrm{T}$-rich sequence following the $\mathrm{CpG}$ methylation site (Klose et al. 2005). Apart from the well-studied MBD family, other proteins have been identified that preferentially bind methylated DNA (Arita et al. 2008; Avvakumov et al. 2008; Daniel et al. 2002; Filion et al. 2006; Prokhortchouk et al. 2001; Sharif et al. 2007; Woo et al. 2007).

\section{$\mathrm{MeCP} 2$}

Several molecular roles have been described for MeCP2: transcriptional repression, activation of transcription, nuclear organization, and splicing. These roles will be elaborated further in the following sections. Alongside with different functions, myriad interactions have been reported (Table 1). Most of these interactions have been isolated under low stringency conditions as $\mathrm{MeCP} 2$ does not form a single stable complex (Klose and Bird 2004), but may interact with other proteins in a context-dependent fashion. It is probably the flexible secondary and tertiary structure of the $\mathrm{MeCP} 2$ protein which allows it to carry out so many diverse functions, as $\mathrm{MeCP} 2$ appears to be a highly disordered protein (Adams et al. 2007).

\section{Transcriptional repression by $\mathrm{MeCP} 2$}

In addition to binding methylated DNA, MeCP2 associates with various co-repressor complexes such as $\operatorname{Sin} 3 \mathrm{a}, \mathrm{NCoR}$, and c-Ski at the sites of its occupance (Jones et al. 1998; Kokura et al. 2001). When targeted to promoter DNA, $\mathrm{MeCP} 2$ causes strong transcriptional repression, suggesting that $\mathrm{MeCP} 2$ might serve as a global transcriptional silencer
(Jones et al. 1998; Nan et al. 1998). Transcriptional profiling of $M e C P 2$-null mice brains, however, displayed only subtle changes in gene expression (Tudor et al. 2002). Such a finding was confirmed in a later study where RNA isolated from the cerebellum of $\mathrm{MeCP} 2$ mutant mice has been subjected to microarray hybridization (Jordan et al. 2007). Interestingly, special AT-rich sequence binding protein 1 (SATB1) was identified as one of the few genes upregulated in two $\mathrm{MeCP} 2$-null mouse models. SATB1 is known to specifically bind to nuclear matrix attachment regions (MARs) and mediate formation of chromatin loops, a feature that has been attributed to the $\mathrm{MeCP} 2$ protein as well (Horike et al. 2005; Weitzel et al. 1997). The most considerable change in expression was attributed to the Irakl gene, which showed a twofold increase in expression. Likewise, a global expression study using cultured fibroblast cell lines from two RTT patients revealed only 49 upregulated and 21 downregulated potential MeCP2 targets, some of which were known to be expressed in brain tissues (Traynor et al. 2002). However, striking differences were observed in different clones obtained from the same RTT patients, which may be indicative of epigenetic instability. Collectively, these data may indicate that $\mathrm{MeCP} 2$ is not strictly involved in (global) transcriptional repression. Recent expression profiling of hypothalamus isolated from $\mathrm{MeCP} 2$-null mice or mice overexpressing $\mathrm{MeCP} 2$ suggests that $\mathrm{MeCP} 2$ can activate transcription on the majority of its targets rather than repressing them (Chahrour et al. 2008). Although it is likely that some genes were affected indirectly in these experiments, chromatin immunoprecipitation (ChIP) showed that MeCP2 binds to promoter regions of some of the activated targets. This activation has been suggested to involve the transcriptional activator CREB-1. These results are highly surprising given the known role of $\mathrm{MeCP} 2$ in transcriptional repression. However, it has also been reported that the majority of 
$\mathrm{MeCP} 2$ bound promoters have low DNA methylation and are actively expressed (Yasui et al. 2007). Moreover, a context-dependent function of MeCP2 may be supported by evidence that $\mathrm{MeCP} 2$-mediated transcriptional repression depends on developmental stage (OB and GJCV, manuscript in preparation), reinforcing the notion that MeCP2 is not a constitutive repressor.

Apart from the "global" $\mathrm{MeCP} 2$ function, its role in the regulation of specific loci has been characterized. The brain-derived neurotrophic factor (BDNF) promoter III appears to be tightly regulated by MeCP2. Studies performed on mouse and rat neuron cultures showed that $\mathrm{MeCP} 2$ vacates its binding site in the BDNF promoter upon membrane depolarization and calcium influx in postmitotic neurons, allowing transcription to proceed (Chen et al. 2003; Martinowich et al. 2003). Western blotting of neural lysates revealed that neuron depolarization causes $\mathrm{MeCP} 2$ phosphorylation and dissociation from the BDNF promoter. Once the activation signal is lost, MeCP2-mediated transcriptional repression is quickly restored. Furthermore, both studies showed that MeCP2 recruits chromatin remodeling activities to repress transcription from BDNF promoter III (Chen et al. 2003; Martinowich et al. 2003). $\mathrm{MeCP} 2$ can be phosphorylated at serine 421 residue by a CaMKII kinase and this phosphorylation is required for the activity-dependent BDNF transcription (Zhou et al. 2006). Moreover, phosphorylation of serine 80 is important for the association of MeCP2 with chromatin, and dephosphorylation of this residue is triggered by calcium influx in neurons (Tao et al. 2009).

\section{Rett syndrome and neural development}

Multiple model systems have been developed to elucidate the molecular functions of MeCP2 and the etiology of RTT disease. RTT is a progressive neurodevelopmental disorder involving a maturational arrest of brain development and synaptic proliferation (Amir et al. 1999; Johnston et al. 2001). The animal model that has yielded the most results is the mouse MeCP2 knockout which exhibits severe neurological symptoms resembling those of RTT patients, including limb clasping and breathing difficulties, as well as reduced brain size and body weight (Chen et al. 2001; Guy et al. 2001). The symptoms mostly occurred between 5 and 6 weeks of age, while $M e C P 2$-null mice eventually died after 2 to 3 months (Chen et al. 2001; Guy et al. 2001). Conditional $\mathrm{MeCP} 2$ depletion in postmitotic neurons resulted in similar, although less severe neural defects suggesting that mature neurons do not function properly in the absence of MeCP2 (Chen et al. 2001). Further functional studies showed that mice carrying an MeCP2 mutation $\left(\mathrm{MeCP}^{308}\right)$ which results in the truncation of the C-terminal domain exhibit many RTT features such as motor dysfunction and seizures (Shahbazian et al. 2002), while overexpression of $\mathrm{MeCP} 2$ in transgenic mice resulted in a severe postnatal, neural phenotype (Collins et al. 2004). Altogether, the data obtained from $\mathrm{MeCP} 2$ manipulation in mice suggest that the mammalian central nervous system requires well-balanced $\mathrm{MeCP} 2$ levels for its proper function. Such a finding is of great importance for therapeutic strategies aiming to re-establish correct MeCP2 levels. It is interesting to note that mice and humans show a different sensitivity to heterozygosity for MeCP2. In both humans and mice, MeCP2 is located on the $\mathrm{X}$ chromosome, which due to random $\mathrm{X}$ inactivation causes mosaicism in affected females. MeCP2 mutations in males usually result in congenital encephalopathy and death in the first 2 years (Geerdink et al. 2002; Zeev et al. 2002). In mice, the lack of any functional MeCP2 (males $\mathrm{MeCP}^{-/ y}$, females $\mathrm{MeCP} 2^{-/-}$) results in a RTT-like phenotype rather than encephalopathy, whereas heterozygous females $\left(\mathrm{MeCP}^{+/-}\right)$ remain viable and fertile (Guy et al. 2001). However, a number of heterozygous $\mathrm{MeCP} 2$-null female mice displayed some RTT features at a later stage (Chen et al. 2001; Guy et al. 2001).

BDNF, an in vivo target of MeCP2 (see above), is important for synaptic plasticity (An et al. 2008; Kuczewski et al. 2009; Smart et al. 2003). To assess the contributions of improper BDNF signaling to the RTT phenotype, Chang and colleagues examined the phenotypes of conditional BNDF mutants as well as the effects of BDNF overexpression on the MeCP2-null mice (Chang et al. 2006). The BDNF mutants displayed many features of the RTT model mice including reduced brain size and hind limb clasping while the overexpression of BDNF in MeCP2 mutant brains resulted in increased life span and a gain of locomotor functions. This shows that correct BDNF signaling is crucial for maintaining normal brain functions and that its alteration contributes to the RTT phenotype. These and other studies (Giacometti et al. 2007; Guy et al. 2007) suggest that MeCP2-depleted neurons do not suffer irreversible damage, and that the restoration of $\mathrm{MeCP} 2$ levels can lead to reduction of neurological symptoms in mice. $\mathrm{MeCP} 2$ expression in postmitotic neurons was able to rescue the RTT-like phenotype (Luikenhuis et al. 2004), in line with earlier observations that $\mathrm{MeCP} 2$ depletion in postmitotic neurons induces RTT-like symptoms (Chen et al. 2001). An alternative therapeutic approach which ameliorates the RTT phenotype has also been recently described (Tropea et al. 2009). Peritoneally injected insulinlike growth factor 1 (IGF-1) peptide increased the life span of MeCP2 mutant mice and led to the improvement of their heart condition and locomotor functions. IGF-1, unlike other potential target molecules such as BDNF, is able to cross the blood-brain barrier which makes it a suitable candidate for therapy. 
In comparison with mice, Xenopus embryos display a much earlier requirement for $\mathrm{MeCP} 2$. Morpholino antisense knockdown of MeCP2 and overexpression of two common RTT mutants demonstrated the requirement for MeCP2 during primary Xenopus neurogenesis (Stancheva et al. 2003). Embryos lacking MeCP2 and embryos overexpressing the RTT truncation mutant display altered neural patterning due to the aberrant expression of the Hairy $2 a$ (hes4) neural repressor and do not survive past the neurulation stage (Stancheva et al. 2003). The Hairy2a repressor is a component of the Notch/Delta signaling pathway (Davis et al. 2001), and its expression inhibits genes such as $\mathrm{N}$ - $\beta$-tubulin involved in neural differentiation. Balanced expression of Hairy $2 a$ appears to be crucial for proper neural patterning, as both MeCP2 knockdown (Hairy $2 a$ upregulation) and R168 MeCP2 mutant overexpression (Hairy $2 a$ downregulation) result in aberrant expression of neural markers (Stancheva et al. 2003). It is interesting to note that in both mice and Xenopus, MeCP2 takes part in neural signaling events albeit in different stages and developmental context. However, this aspect of $\mathrm{MeCP} 2$ function may not capture all its activities, which is discussed in the next paragraph.

\section{MeCP2, nuclear organization, and splicing}

The number of functions attributed to the $\mathrm{MeCP} 2$ protein has grown during the last couple of years, well beyond transcriptional repression (Chadwick and Wade 2007; Dhasarathy and Wade 2008). An MeCP2 ChIP cloning and sequencing approach revealed a number of sequences mapping to the imprinted gene cluster on chromosome 6 (Horike et al. 2005), which includes the Dlx5-Dlx6 locus. That locus was of particular interest since the maternally imprinted gene Dlx5 is involved in the pathway synthesizing $\gamma$-aminobutyric acid (GABA) which is produced less in RTT patients. Both Dlx5 and Dlx6 were found somewhat upregulated in the cortex of MeCP2-null mice, and the main reason for that seemed to be the loss of silent chromatin loops on the imprinted allele; the formation of the loops depended on the presence of MeCP2. However, a later study showed that in a number of systems, Dlx 5 and Dlx6 are expressed from both alleles (Schule et al. 2007). Biallelic expression of Dlx5 was also reported in lymphoblasts originating from autistic spectrum disorder patients and healthy control individuals (Nakashima et al. 2009).

$\mathrm{MeCP} 2$ has also been described as a splice regulator, interacting with YB-1, a component of messenger ribonucleoprotein particles, in brain nuclear extracts (Young et al. 2005). This association proved to be sensitive to RNAse treatment, implying that the MeCP2-YB-1 complex requires RNA for its formation or stability. Microarray splicing analysis of cerebral cortex mRNA isolated from
RTT mutant mice showed a number of aberrantly spliced genes, including Dlx5. The exact function of the MeCP2YB1 interaction remains unknown; however, it is interesting to note that several links exist between proteins associated with DNA methylation-mediated repression and RNA processing (Goll et al. 2006; Jeffery and Nakielny 2004). Moreover, chicken MeCP2 (ARBP) displays high affinity for matrix/scaffold attachment regions (MARs/ SARs; Weitzel et al. 1997), and the nuclear matrix is also associated with the RNA splicing machinery (Chabot et al. 1995; Wagner et al. 2003; Zeitlin et al. 1987). It is therefore tempting to speculate that $\mathrm{MeCP} 2$, chromatin looping, and RNA splicing are functionally linked. It is possible that an architectural role of MeCP2 unifies the diverse set of molecular functions attributed to this protein (repression, activation, splicing, organizing long-range interactions), similar to how the insulator binding protein CTCF causes activation or repression of transcription in a context and DNA methylation-dependent fashion (Bartkuhn and Renkawitz 2008; Wallace and Felsenfeld 2007).

\section{MBD1}

MBD1 is the largest MBD family member and it also represses transcription through its repression domain like other family members. It is known to act as a transcriptional repressor both in vivo and in vitro, and depending on the splicing isoform, it can bind methylated as well as unmethylated DNA (Fujita et al. 2000; Ohki et al. 1999). Like the other family members, MBD1 associates with chromatin modifiers such as the Suv39h1-HP1 complex to enhance DNA methylation-mediated transcriptional repression (Fujita et al. 2003). The functional importance of MBD1 was demonstrated in human HeLa cells, where MBD1 was shown to associate with the H3K9 methyltransferase SETDB1 (Sarraf and Stancheva 2004). During S phase the MBD1-SETDB1 complex is recruited to chromatin by the chromatin assembly factor CAF1 to establish new H3K9 methyl marks. The removal of DNA methylation disrupts the formation of MBD1-SETDB1-CAF1 interaction on the p53BP2 promoter, which leads to the loss of H3K9 methylation. The cooperation of MBD1 and CAF1 (p150) had been described before (Reese et al. 2003) as well as the involvement of CAF1 in replication-coupled histone mark deposition (Mello and Almouzni 2001). The MBD1-SETDB1 complex formation is negatively regulated by PIAS1 and PIAS3 SUMO-ligases and sumoylated MBD1 is no longer able to form the complex (Lyst et al. 2006). Since a sumoylated MBD1 can bind methylated DNA but fails to recruit SETDB1, it is possible that the balance between SETDB1 and the SUMO ligase determines the extent of MBD1-dependent repression of methylated DNA sequences. An MBD1 mouse knockout 
has been obtained, but no severe developmental defects were found. MBD1-null mice had a normal morphology and appeared healthy, although they carried a number of minor neural defects like reduced hippocampal neurogenesis and had problems with spatial learning. Another interesting feature of this knockout was reduced genomic stability and an increase in expression of the Intracisternal-A particle retrotransposon (Zhao et al. 2003). As H3K9 methylation is involved in the silencing of genomic repetitive elements (Martens et al. 2005; Mikkelsen et al. 2007), the lack of proper $\mathrm{H} 3 \mathrm{~K} 9$ methylation may have led to reactivation of retrotransposon sequences in the $M B D 1$-null mice.

\section{MBD2}

The third member of the MBD family, MBD2, is a 44-kDa protein which shares extensive sequence homology with MBD3 (Wade 2001). MBD2 is able to bind methylated CpGs in vitro and in vivo and confer DNA methylationmediated transcriptional silencing through its repression domain (Boeke et al. 2000; Ng et al. 1999). The repression established by MBD2 is sensitive to HDAC inhibitors, in line with its association with HDAC1 and HDAC2 in the Mi-2/NuRD chromatin remodeling complex (Zhang et al. 1999). MBD2-null mice developed normally and remained viable and fertile, although $M B D 2$-null mothers failed to nurture their pups properly (Hendrich et al. 2001). The connection between the loss of MBD2 and the observed maternal behavior is unclear. A recent study involving a triple MeCP2/MBD2/Kaiso mouse knockout showed no phenotype except a minor delay in neural differentiation, ruling out redundancy as an explanation for the absence of a phenotype when knocked out separately (Martin Caballero et al. 2009). MBD2, however, does play a role in helper Tcell differentiation (Hutchins et al. 2002). Normally, the induction of IL-4 during differentiation requires the GATA3 activator, however, in MBD2-null mice Gata-3 is no longer needed for IL-4 induction and as a result IL-4 is ectopically expressed in undifferentiated helper $\mathrm{T}$ cells (Hutchins et al. 2002). A recent study showed that MBD2 influences Xchromosome inactivation (Barr et al. 2007). Expression of the $\mathrm{X}$-linked non-coding Xist gene inactivates the $\mathrm{X}$ chromosome in cis, so the active $\mathrm{X}$-chromosome has to silence its own Xist allele in order to prevent inactivation. MBD2 null cells displayed a low level reactivation of Xist expression, whereas the depletion of MBD1, MeCP2, and Kaiso did not induce Xist upregulation. Interestingly, MBD2 antisense targeting in cultured cells showed that MBD2-depleted, lung, or colorectal cancer cell lines fail to develop tumors once injected into nude mice (Campbell et al. 2004); moreover, mouse models for intestinal tumorigenesis show a reduced tumorigenesis rate in the absence of MBD2 (Sansom et al. 2003).
MBD3

Mammalian methyl-CpG binding protein 3 (MBD3), which in contrast to amphibian MBD3 is not able to bind methylated DNA, is an essential subunit of the Mi-2/NuRD chromatin remodeling complex (Saito and Ishikawa 2002; Zhang et al. 1999). MBD2 and MBD3 associate with Mi-2/ NuRD in a mutually exclusive way, thereby forming two distinct complexes (Denslow and Wade 2007; Feng and Zhang 2001; Le Guezennec et al. 2006). The association of an MBD related to mammalian MBD2/3 with NuRD has been conserved in Drosophila, highlighting the importance of this interaction (Marhold et al. 2004a, b). In spite of the striking sequence similarity between MBD2 and MBD3, the two proteins do not carry out redundant functions during early development. In contrast to MBD2-null mice which only displayed a mild maternal phenotype as discussed above, $M B D 3$-null embryos are severely affected at day 8.5 and die. MBD3-null ES were seriously compromised in their ability to differentiate (Kaji et al. 2006; Kaji et al. 2007) as they failed to shut down the expression of undifferentiated ES cell markers such as Oct4, Nanog, and Rexl. In line with that observation, embryonic bodies formed from $M B D 3$-null cells did not express markers like Brachyury and Gata6. Aberrant gene expression in MBD3-null cells is the most probable reason why cells of the inner cell mass fail to develop into late epiblast after implantation (Kaji et al. 2007). Interestingly, MTA-3, a cell type-specific subunit of an MBD3containing Mi-2/NuRD complex, proved to be indispensable for the B lymphocyte differentiation program (Fujita et al. 2004). MBD3 knockdown in X. laevis embryos severely disrupted embryogenesis (Iwano et al. 2004). A morpholino antisense inhibiting the translation of both MBD3 and MBD3LF (the long form of MBD3), injected at low concentrations, induced a defective eye formation phenotype which occurred due to the misregulation of the Pax6 gene. In contrast to mammals where both MBD2 and MBD3 interact with Mi-2/NuRD, Xenopus MBD3 but not MBD2 has been shown to be a subunit of the Mi-2/NuRD complex (Wade et al. 1999).

\section{MBD4}

The last member of the MBD family, MBD4, is a thymine glycosylase which acts as a DNA repair protein and targets sites of cytosine deamination (Hendrich et al. 1999). The $\mathrm{CpG}$ dinucleotide is under-represented in methylated genomes. The reason for that is spontaneous hydrolytic deamination of methylated cytosine which causes $\mathrm{mCpG}-$ TpG transitions (Bird 1980), whereas non-methylated CpG mutates to UpG. MBD4 is able to excise and repair both mutated nucleotides (Hendrich et al. 1999). In line with this 
function, mutations in MBD4 have been found in various human carcinomas associated with microsatellite instability (Riccio et al. 1999). MBD4-null mice had a two to three times higher number of $\mathrm{mCpG}-\mathrm{TpG}$ transitions showing that MBD4 acts to reduce the $\mathrm{mCpG}-\mathrm{TpG}$ mutation rate (Millar et al. 2002; Wong et al. 2002). This relatively mild mutator phenotype suggests that other thymine glycosylases might carry out similar functions. In both studies, mice appeared healthy and did not show any physical abnormalities. Only when crossed with mice carrying a germline mutation in the Apc (adenomatous polyposis coli) gene, the MBD4-null animals showed accelerated tumor formation (Millar et al. 2002) or accelerated tumor progression (Wong et al. 2002). The potential function of MBD4 as a transcriptional repressor was demonstrated by a series of in vitro repression assays (Kondo et al. 2005). LexA-MBD fusions, when targeted to reporter constructs, showed that MBD4 is capable of silencing transcription with the same efficiency as MBD2 and MeCP2 (Kondo et al. 2005). Furthermore, this MBD4-directed repression was mediated by interactions with $\operatorname{Sin} 3$ and HDAC1, well-known partners of the MBD family members. Whether this transcriptional potential of MBD4 reflects its physiological role still needs to be tested. Also, a recent study in zebrafish provided evidence for a role of MBD4 in active demethylation (Rai et al. 2008). It will be interesting to see whether MBD4 can act in a similar way in higher organisms and whether other thymine glycosylases can carry out similar functions.

\section{Kaiso (ZBTB33), ZBTB4, and ZBTB38}

Besides the MBD family, other proteins such as Kaiso, ZBTB4, and ZBTB38 that are able to preferentially or specifically bind methylated DNA through zinc-finger domains have also been described (Filion et al. 2006; Prokhortchouk et al. 2001). Since its discovery, Kaiso has been attributed a number of important functions. Kaiso antisense knockdown in $X$. laevis caused a premature activation of zygotic transcription which eventually led to apoptosis and developmental arrest (Ruzov et al. 2004). This phenotype closely resembled the one induced by the DNMT1 antisense depletion (Stancheva and Meehan 2000), suggesting that DNA methylation-mediated repression mechanisms are partly responsible for repression of embryonic transcription before the mid-blastula transition. A Kaiso knockout in mice resulted in no apparent abnormalities (Prokhortchouk et al. 2006). However, when Kaiso-null mice were crossed with $\mathrm{Apc}^{\mathrm{Min} /+}$ mice susceptible for intestinal tumorigenesis, Kaiso knockouts displayed a delayed onset of tumor formation. Functional studies in mammals and amphibians (Prokhortchouk et al. 2006; Ruzov et al. 2004; Ruzov et al. 2009) suggest that the biological roles of Kaiso are not conserved. In addition to
Kaiso, two other zinc-finger proteins capable of binding methylated DNA have been identified (Filion et al. 2006). ZBTB4 and ZBTB38 require only one methylated $\mathrm{CpG}$ for binding, unlike Kaiso which requires two. Both ZBTB4 and ZBTB38 are able to repress transcription in transfection assays, and whereas they display considerably different tissue expression profiles, both of them accumulate in the brain.

\section{Concluding remarks}

MBD proteins were initially described as interpreters of the DNA methylation mark. However, they seem to affect normal development and (patho) physiology by a wide variety of mechanisms, some of which are yet to be characterized. Developmental requirements for methylCpG binding protein function differ among species. Generally, MBD depletion in Xenopus causes more severe developmental defects than in mice. The exception is MBD3 which, in spite the lack of specific DNAmethylation binding, is indispensable for early mouse development. In humans, MeCP2 inactivation on one of the $\mathrm{X}$ chromosomes causes Rett syndrome in girls, whereas boys with a MeCP2 mutation are affected even more severely. In that respect, mice are less sensitive to loss of MeCP2 because a Rett-like phenotype is observed only when both MeCP2 alleles are deleted (Chen et al. 2001; Guy et al. 2001). Notwithstanding the differences observed upon MeCP2 depletion, it is interesting that both Xenopus and mice employ $\mathrm{MeCP} 2$ for gene regulation in response to neural signaling (Martinowich et al. 2003; Stancheva et al. 2003). Encouraging advances have been made in reversing Rett-like symptoms in mice (Giacometti et al. 2007; Guy et al. 2007; Luikenhuis et al. 2004; Tropea et al. 2009). A better insight in the action of MeCP2 at the molecular genomic level may unify the diverse processes MeCP2 has been attributed a function. In the near future, a greater understanding of methyl-CpG binding protein function will require integrated analyses of genome-wide binding profiles, long-range interactions in chromatin, and the regulatory role of posttranslational modifications. The rewards will be manifold, as DNA methylation makes an essential epigenetic contribution to genome integrity and function.

Acknowledgments The authors thank Arjen Brinkman for helpful suggestions and critical reading of the manuscript. Work in the lab of GJCV has been supported by the Netherlands Organization for Scientific Research, Earth and Life Sciences Council (NWO-ALW Vidi grant 864.03.002).

Open Access This article is distributed under the terms of the Creative Commons Attribution Noncommercial License which permits any noncommercial use, distribution, and reproduction in any medium, provided the original author(s) and source are credited. 


\section{References}

Aapola U, Kawasaki K, Scott HS, Ollila J, Vihinen M, Heino M, Shintani A, Minoshima S, Krohn K, Antonarakis SE, Shimizu N, Kudoh J, Peterson P (2000) Isolation and initial characterization of a novel zinc finger gene, DNMT3L, on 21q22.3, related to the cytosine-5-methyltransferase 3 gene family. Genomics 65:293298

Aapola U, Liiv I, Peterson P (2002) Imprinting regulator DNMT3L is a transcriptional repressor associated with histone deacetylase activity. Nucleic Acids Res 30:3602-3608

Adams VH, McBryant SJ, Wade PA, Woodcock CL, Hansen JC (2007) Intrinsic disorder and autonomous domain function in the multifunctional nuclear protein, MeCP2. J Biol Chem 282: 15057-15064

Agarwal N, Hardt T, Brero A, Nowak D, Rothbauer U, Becker A, Leonhardt H, Cardoso MC (2007) MeCP2 interacts with HP1 and modulates its heterochromatin association during myogenic differentiation. Nucleic Acids Res 35:5402-5408

Amir RE, Van den Veyver IB, Wan M, Tran CQ, Francke U, Zoghbi HY (1999) Rett syndrome is caused by mutations in X-linked MECP2, encoding methyl-CpG-binding protein 2. Nat Genet 23:185-188

An JJ, Gharami K, Liao GY, Woo NH, Lau AG, Vanevski F, Torre ER, Jones KR, Feng Y, Lu B, Xu B (2008) Distinct role of long 3' UTR BDNF mRNA in spine morphology and synaptic plasticity in hippocampal neurons. Cell 134:175-187

Angrisano T, Lembo F, Pero R, Natale F, Fusco A, Avvedimento VE, Bruni CB, Chiariotti L (2006) TACC3 mediates the association of MBD2 with histone acetyltransferases and relieves transcriptional repression of methylated promoters. Nucleic Acids Res 34:364-372

Antequera F, Tamame M, Villanueva JR, Santos T (1984) DNA methylation in the fungi. J Biol Chem 259:8033-8036

Arita K, Ariyoshi M, Tochio H, Nakamura Y, Shirakawa M (2008) Recognition of hemi-methylated DNA by the SRA protein UHRF1 by a base-flipping mechanism. Nature 455:818-821

Avvakumov GV, Walker JR, Xue S, Li Y, Duan S, Bronner C, Arrowsmith CH, Dhe-Paganon S (2008) Structural basis for recognition of hemi-methylated DNA by the SRA domain of human UHRF1. Nature 455:822-825

Ballas N, Grunseich C, Lu DD, Speh JC, Mandel G (2005) REST and its corepressors mediate plasticity of neuronal gene chromatin throughout neurogenesis. Cell 121:645-657

Ballestar E, Paz MF, Valle L, Wei S, Fraga MF, Espada J, Cigudosa JC, Huang TH, Esteller M (2003) Methyl-CpG binding proteins identify novel sites of epigenetic inactivation in human cancer. EMBO J 22:6335-6345

Barchuk AR, Cristino AS, Kucharski R, Costa LF, Simoes ZL, Maleszka R (2007) Molecular determinants of caste differentiation in the highly eusocial honeybee Apis mellifera. BMC Dev Biol 7:70

Barr H, Hermann A, Berger J, Tsai HH, Adie K, Prokhortchouk A, Hendrich B, Bird A (2007) Mbd2 contributes to DNA methylation-directed repression of the Xist gene. Mol Cell Biol 27:3750-3757

Barreto G, Schafer A, Marhold J, Stach D, Swaminathan SK, Handa V, Doderlein G, Maltry N, Wu W, Lyko F, Niehrs C (2007) Gadd45a promotes epigenetic gene activation by repair-mediated DNA demethylation. Nature 445:671-675

Bartkuhn M, Renkawitz R (2008) Long range chromatin interactions involved in gene regulation. Biochim Biophys Acta 1783:21612166

Bellacosa A, Cicchillitti L, Schepis F, Riccio A, Yeung AT, Matsumoto Y, Golemis EA, Genuardi M, Neri G (1999)
MED1, a novel human methyl-CpG-binding endonuclease, interacts with DNA mismatch repair protein MLH1. Proc Natl Acad Sci U S A 96:3969-3974

Bestor TH, Tycko B (1996) Creation of genomic methylation patterns. Nat Genet 12:363-367

Bhattacharya SK, Ramchandani S, Cervoni N, Szyf M (1999) A mammalian protein with specific demethylase activity for $\mathrm{mCpG}$ DNA. Nature 397:579-583

Bibikova M, Chudin E, Wu B, Zhou L, Garcia EW, Liu Y, Shin S, Plaia TW, Auerbach JM, Arking DE, Gonzalez R, Crook J, Davidson B, Schulz TC, Robins A, Khanna A, Sartipy P, Hyllner J, Vanguri P, Savant-Bhonsale S, Smith AK, Chakravarti A, Maitra A, Rao M, Barker DL, Loring JF, Fan JB (2006a) Human embryonic stem cells have a unique epigenetic signature. Genome Res 16:1075-1083

Bibikova M, Lin Z, Zhou L, Chudin E, Garcia EW, Wu B, Doucet D, Thomas NJ, Wang Y, Vollmer E, Goldmann T, Seifart C, Jiang W, Barker DL, Chee MS, Floros J, Fan JB (2006b) Highthroughput DNA methylation profiling using universal bead arrays. Genome Res 16:383-393

Bird A (2002) DNA methylation patterns and epigenetic memory. Genes Dev 16:6-21

Bird AP (1980) DNA methylation and the frequency of CpG in animal DNA. Nucleic Acids Res 8:1499-1504

Bird AP (1986) CpG-rich islands and the function of DNA methylation. Nature 321:209-213

Bittel DC, Butler MG (2005) Prader-Willi syndrome: clinical genetics, cytogenetics and molecular biology. Expert Rev Mol Med 7:1-20

Boeke J, Ammerpohl O, Kegel S, Moehren U, Renkawitz R (2000) The minimal repression domain of MBD2b overlaps with the methyl-CpG-binding domain and binds directly to Sin3A. J Biol Chem 275:34963-34967

Bourc'his D, Xu GL, Lin CS, Bollman B, Bestor TH (2001) Dnmt3L and the establishment of maternal genomic imprints. Science 294:2536-2539

Brackertz M, Boeke J, Zhang R, Renkawitz R (2002) Two highly related p66 proteins comprise a new family of potent transcriptional repressors interacting with MBD2 and MBD3. J Biol Chem 277:40958-40966

Brown SE, Suderman MJ, Hallett M, Szyf M (2008) DNA demethylation induced by the methyl-CpG-binding domain protein MBD3. Gene 420:99-106

Brunner AL, Johnson DS, Kim SW, Valouev A, Reddy TE, Neff NF, Anton E, Medina C, Nguyen L, Chiao E, Oyolu CB, Schroth GP, Absher DM, Baker JC, Myers RM (2009) Distinct DNA methylation patterns characterize differentiated human embryonic stem cells and developing human fetal liver. Genome Res 19:1044-1056

Campanero MR, Armstrong MI, Flemington EK (2000) CpG methylation as a mechanism for the regulation of E2F activity. Proc Natl Acad Sci U S A 97:6481-6486

Campbell PM, Bovenzi V, Szyf M (2004) Methylated DNA-binding protein 2 antisense inhibitors suppress tumourigenesis of human cancer cell lines in vitro and in vivo. Carcinogenesis 25:499-507

Chabot B, Bisotto S, Vincent M (1995) The nuclear matrix phosphoprotein p255 associates with splicing complexes as part of the [U4/U6.U5] tri-snRNP particle. Nucleic Acids Res 23: $3206-3213$

Chadwick LH, Wade PA (2007) MeCP2 in Rett syndrome: transcriptional repressor or chromatin architectural protein? Curr Opin Genet Dev 17:121-125

Chahrour M, Jung SY, Shaw C, Zhou X, Wong ST, Qin J, Zoghbi HY (2008) MeCP2, a key contributor to neurological disease, activates and represses transcription. Science 320:1224-1229

Chang Q, Khare G, Dani V, Nelson S, Jaenisch R (2006) The disease progression of Mecp2 mutant mice is affected by the level of BDNF expression. Neuron 49:341-348 
Chen RZ, Akbarian S, Tudor M, Jaenisch R (2001) Deficiency of methyl-CpG binding protein-2 in CNS neurons results in a Rettlike phenotype in mice. Nat Genet 27:327-331

Chen WG, Chang Q, Lin Y, Meissner A, West AE, Griffith EC, Jaenisch R, Greenberg ME (2003) Derepression of BDNF transcription involves calcium-dependent phosphorylation of $\mathrm{MeCP} 2$. Science 302:885-889

Clouaire T, Stancheva I (2008) Methyl-CpG binding proteins: specialized transcriptional repressors or structural components of chromatin? Cell Mol Life Sci 65:1509-1522

Colhoun EH, Smith MV (1960) Neurohormonal properties of royal jelly. Nature 188:854-855

Collins AL, Levenson JM, Vilaythong AP, Richman R, Armstrong DL, Noebels JL, David Sweatt J, Zoghbi HY (2004) Mild overexpression of $\mathrm{MeCP} 2$ causes a progressive neurological disorder in mice. Hum Mol Genet 13:2679-2689

Daniel JM, Reynolds AB (1999) The catenin p120(ctn) interacts with Kaiso, a novel BTB/POZ domain zinc finger transcription factor. Mol Cell Biol 19:3614-3623

Daniel JM, Spring CM, Crawford HC, Reynolds AB, Baig A (2002) The p120(ctn)-binding partner Kaiso is a bi-modal DNA-binding protein that recognizes both a sequence-specific consensus and methylated CpG dinucleotides. Nucleic Acids Res 30:2911-2919

Davis RL, Turner DL, Evans LM, Kirschner MW (2001) Molecular targets of vertebrate segmentation: two mechanisms control segmental expression of Xenopus hairy2 during somite formation. Dev Cell 1:553-565

Dean W, Santos F, Stojkovic M, Zakhartchenko V, Walter J, Wolf E, Reik W (2001) Conservation of methylation reprogramming in mammalian development: aberrant reprogramming in cloned embryos. Proc Natl Acad Sci U S A 98:13734-13738

Delaval K, Feil R (2004) Epigenetic regulation of mammalian genomic imprinting. Curr Opin Genet Dev 14:188-195

Denslow SA, Wade PA (2007) The human Mi-2/NuRD complex and gene regulation. Oncogene 26:5433-5438

Deplus R, Brenner C, Burgers WA, Putmans P, Kouzarides T, de Launoit Y, Fuks F (2002) Dnmt3L is a transcriptional repressor that recruits histone deacetylase. Nucleic Acids Res 30:38313838

Deshpande AM, Dai YS, Kim Y, Kim J, Kimlin L, Gao K, Wong DT (2009) Cdk2ap1 is required for epigenetic silencing of Oct4 during murine embryonic stem cell differentiation. J Biol Chem 284 (10):6043-6047

Detich N, Theberge J, Szyf M (2002) Promoter-specific activation and demethylation by MBD2/demethylase. J Biol Chem 277:3579135794

Dhasarathy A, Wade PA (2008) The MBD protein family-reading an epigenetic mark? Mutat Res 647:39-43

Dintilhac A, Bernues J (2002) HMGB1 interacts with many apparently unrelated proteins by recognizing short amino acid sequences. J Biol Chem 277:7021-7028

Eckhardt F, Lewin J, Cortese R, Rakyan VK, Attwood J, Burger M, Burton J, Cox TV, Davies R, Down TA, Haefliger C, Horton R, Howe K, Jackson DK, Kunde J, Koenig C, Liddle J, Niblett D, Otto T, Pettett R, Seemann S, Thompson C, West T, Rogers J, Olek A, Berlin K, Beck S (2006) DNA methylation profiling of human chromosomes 6, 20 and 22. Nat Genet 38:1378-1385

Ego T, Tanaka Y, Shimotohno K (2005) Interaction of HTLV-1 Tax and methyl-CpG-binding domain 2 positively regulates the gene expression from the hypermethylated LTR. Oncogene 24:1914-1923

Engel N, Tront JS, Erinle T, Nguyen N, Latham KE, Sapienza C, Hoffman B, Liebermann DA (2009) Conserved DNA methylation in Gadd45a(-/-) mice. Epigenetics 4(2):98-99

Fatemi M, Hermann A, Gowher H, Jeltsch A (2002) Dnmt3a and Dnmt1 functionally cooperate during de novo methylation of DNA. Eur J Biochem 269:4981-4984
Feng Q, Zhang Y (2001) The MeCP1 complex represses transcription through preferential binding, remodeling, and deacetylating methylated nucleosomes. Genes Dev 15:827-832

Field LM, Lyko F, Mandrioli M, Prantera G (2004) DNA methylation in insects. Insect Mol Biol 13:109-115

Filion GJ, Zhenilo S, Salozhin S, Yamada D, Prokhortchouk E, Defossez PA (2006) A family of human zinc finger proteins that bind methylated DNA and repress transcription. Mol Cell Biol 26:169-181

Fraga MF, Ballestar E, Montoya G, Taysavang P, Wade PA, Esteller M (2003) The affinity of different MBD proteins for a specific methylated locus depends on their intrinsic binding properties. Nucleic Acids Res 31:1765-1774

Fujita N, Shimotake N, Ohki I, Chiba T, Saya H, Shirakawa M, Nakao M (2000) Mechanism of transcriptional regulation by methylCpG binding protein MBD1. Mol Cell Biol 20:5107-5118

Fujita N, Watanabe S, Ichimura T, Tsuruzoe S, Shinkai Y, Tachibana M, Chiba T, Nakao M (2003) Methyl-CpG binding domain 1 (MBD1) interacts with the Suv39h1-HP1 heterochromatic complex for DNA methylation-based transcriptional repression. J Biol Chem 278:24132-24138

Fujita N, Jaye DL, Geigerman C, Akyildiz A, Mooney MR, Boss JM, Wade PA (2004) MTA3 and the Mi-2/NuRD complex regulate cell fate during B lymphocyte differentiation. Cell 119:75-86

Fuks F, Hurd PJ, Deplus R, Kouzarides T (2003a) The DNA methyltransferases associate with HP1 and the SUV39H1 histone methyltransferase. Nucleic Acids Res 31:2305-2312

Fuks F, Hurd PJ, Wolf D, Nan X, Bird AP, Kouzarides T (2003b) The methyl-CpG-binding protein $\mathrm{MeCP} 2$ links DNA methylation to histone methylation. J Biol Chem 278:4035-4040

Fukushige S, Kondo E, Gu Z, Suzuki H, Horii A (2006) RET finger protein enhances MBD2- and MBD4-dependent transcriptional repression. Biochem Biophys Res Commun 351:85-92

Geerdink N, Rotteveel JJ, Lammens M, Sistermans EA, Heikens GT, Gabreels FJ, Mullaart RA, Hamel BC (2002) MECP2 mutation in a boy with severe neonatal encephalopathy: clinical, neuropathological and molecular findings. Neuropediatrics 33:33-36

Giacometti E, Luikenhuis S, Beard C, Jaenisch R (2007) Partial rescue of $\mathrm{MeCP} 2$ deficiency by postnatal activation of MeCP2. Proc Natl Acad Sci U S A 104:1931-1936

Goll MG, Kirpekar F, Maggert KA, Yoder JA, Hsieh CL, Zhang X, Golic KG, Jacobsen SE, Bestor TH (2006) Methylation of tRNAAsp by the DNA methyltransferase homolog Dnmt2. Science 311:395-398

Gowher H, Stockdale CJ, Goyal R, Ferreira H, Owen-Hughes T, Jeltsch A (2005) De novo methylation of nucleosomal DNA by the mammalian Dnmt1 and Dnmt3A DNA methyltransferases. Biochemistry 44:9899-9904

Gu P, Le Menuet D, Chung AC, Cooney AJ (2006) Differential recruitment of methylated $\mathrm{CpG}$ binding domains by the orphan receptor GCNF initiates the repression and silencing of Oct4 expression. Mol Cell Biol 26:9471-9483

Guy J, Hendrich B, Holmes M, Martin JE, Bird A (2001) A mouse Mecp2-null mutation causes neurological symptoms that mimic Rett syndrome. Nat Genet 27:322-326

Guy J, Gan J, Selfridge J, Cobb S, Bird A (2007) Reversal of neurological defects in a mouse model of Rett syndrome. Science 315:1143-1147

Harikrishnan KN, Chow MZ, Baker EK, Pal S, Bassal S, Brasacchio D, Wang L, Craig JM, Jones PL, Sif S, El-Osta A (2005) Brahma links the SWI/SNF chromatin-remodeling complex with MeCP2dependent transcriptional silencing. Nat Genet 37:254-264

Hata K, Okano M, Lei H, Li E (2002) Dnmt3L cooperates with the Dnmt3 family of de novo DNA methyltransferases to establish maternal imprints in mice. Development 129:1983-1993

Hendrich B, Bird A (1998) Identification and characterization of a family of mammalian methyl-CpG binding proteins. Mol Cell Biol 18:6538-6547 
Hendrich B, Hardeland U, Ng HH, Jiricny J, Bird A (1999) The thymine glycosylase MBD4 can bind to the product of deamination at methylated CpG sites. Nature 401:301-304

Hendrich B, Guy J, Ramsahoye B, Wilson VA, Bird A (2001) Closely related proteins MBD2 and MBD3 play distinctive but interacting roles in mouse development. Genes Dev 15:710-723

Hendrich B, Tweedie S (2003) The methyl-CpG binding domain and the evolving role of DNA methylation in animals. Trends Genet 19:269-277

Hermann A, Schmitt S, Jeltsch A (2003) The human Dnmt2 has residual DNA-(cytosine-C5) methyltransferase activity. J Biol Chem 278:31717-31721

Horike S, Cai S, Miyano M, Cheng JF, Kohwi-Shigematsu T (2005) Loss of silent-chromatin looping and impaired imprinting of DLX5 in Rett syndrome. Nat Genet 37:31-40

Howell CY, Bestor TH, Ding F, Latham KE, Mertineit C, Trasler JM, Chaillet JR (2001) Genomic imprinting disrupted by a maternal effect mutation in the Dnmt1 gene. Cell 104:829-838

Hu K, Nan X, Bird A, Wang W (2006) Testing for association between $\mathrm{MeCP} 2$ and the brahma-associated SWI/SNF chromatinremodeling complex. Nat Genet 38:962-964 author reply 964-967

Hung MS, Karthikeyan N, Huang B, Koo HC, Kiger J, Shen CJ (1999) Drosophila proteins related to vertebrate DNA (5cytosine) methyltransferases. Proc Natl Acad Sci U S A 96: 11940-11945

Hutchins AS, Mullen AC, Lee HW, Sykes KJ, High FA, Hendrich BD, Bird AP, Reiner SL (2002) Gene silencing quantitatively controls the function of a developmental trans-activator. Mol Cell 10:81-91

Ichimura T, Watanabe S, Sakamoto Y, Aoto T, Fujita N, Nakao M (2005) Transcriptional repression and heterochromatin formation by MBD1 and MCAF/AM family proteins. J Biol Chem 280:13928-13935

Iguchi-Ariga SM, Schaffner W (1989) CpG methylation of the cAMPresponsive enhancer/promoter sequence TGACGTCA abolishes specific factor binding as well as transcriptional activation. Genes Dev 3:612-619

Iwano H, Nakamura M, Tajima S (2004) Xenopus MBD3 plays a crucial role in an early stage of development. Dev Biol 268:416-428

Jackson-Grusby L, Beard C, Possemato R, Tudor M, Fambrough D, Csankovszki G, Dausman J, Lee P, Wilson C, Lander E, Jaenisch $\mathrm{R}$ (2001) Loss of genomic methylation causes p53-dependent apoptosis and epigenetic deregulation. Nat Genet 27:31-39

Jeffery L, Nakielny S (2004) Components of the DNA methylation system of chromatin control are RNA-binding proteins. J Biol Chem 279:49479-49487

Jeltsch A (2006) Molecular enzymology of mammalian DNA methyltransferases. Curr Top Microbiol Immunol 301:203-225

Jin SG, Guo C, Pfeifer GP (2008) GADD45A does not promote DNA demethylation. PLoS Genet 4:e1000013

Johnston MV, Jeon OH, Pevsner J, Blue ME, Naidu S (2001) Neurobiology of Rett syndrome: a genetic disorder of synapse development. Brain Dev 23(Suppl 1):S206-213

Jones PL, Veenstra GJ, Wade PA, Vermaak D, Kass SU, Landsberger N, Strouboulis J, Wolffe AP (1998) Methylated DNA and $\mathrm{MeCP} 2$ recruit histone deacetylase to repress transcription. Nat Genet 19:187-191

Jordan C, Li HH, Kwan HC, Francke U (2007) Cerebellar gene expression profiles of mouse models for Rett syndrome reveal novel MeCP2 targets. BMC Med Genet 8:36

Jorgensen HF, Ben-Porath I, Bird AP (2004) Mbd1 is recruited to both methylated and nonmethylated CpGs via distinct DNA binding domains. Mol Cell Biol 24:3387-3395

Kaji K, Caballero IM, MacLeod R, Nichols J, Wilson VA, Hendrich B (2006) The NuRD component Mbd3 is required for pluripotency of embryonic stem cells. Nat Cell Biol 8:285-292
Kaji K, Nichols J, Hendrich B (2007) Mbd3, a component of the NuRD co-repressor complex, is required for development of pluripotent cells. Development 134:1123-1132

Kiefer JC (2007) Epigenetics in development. Dev Dyn 236:11441156

Kimura H, Shiota K (2003) Methyl-CpG-binding protein, MeCP2, is a target molecule for maintenance DNA methyltransferase, Dnmt1. J Biol Chem 278:4806-4812

Klose RJ, Bird AP (2004) MeCP2 behaves as an elongated monomer that does not stably associate with the Sin3a chromatin remodeling complex. J Biol Chem 279:46490-46496

Klose RJ, Bird AP (2006) Genomic DNA methylation: the mark and its mediators. Trends Biochem Sci 31:89-97

Klose RJ, Sarraf SA, Schmiedeberg L, McDermott SM, Stancheva I, Bird AP (2005) DNA binding selectivity of MeCP2 due to a requirement for $\mathrm{A} / \mathrm{T}$ sequences adjacent to methyl-CpG. Mol Cell 19:667-678

Kokura K, Kaul SC, Wadhwa R, Nomura T, Khan MM, Shinagawa T, Yasukawa T, Colmenares C, Ishii S (2001) The Ski protein family is required for $\mathrm{MeCP} 2$-mediated transcriptional repression. J Biol Chem 276:34115-34121

Kondo E, Gu Z, Horii A, Fukushige S (2005) The thymine DNA glycosylase MBD4 represses transcription and is associated with methylated p16(INK4a) and hMLH1 genes. Mol Cell Biol 25:4388-4396

Kucharski R, Maleszka J, Foret S, Maleszka R (2008) Nutritional control of reproductive status in honeybees via DNA methylation. Science 319:1827-1830

Kuczewski N, Porcher C, Lessmann V, Medina I, Gaiarsa JL (2009) Activity-dependent dendritic release of BDNF and biological consequences. Mol Neurobiol 39:37-49

Kunert N, Marhold J, Stanke J, Stach D, Lyko F (2003) A Dnmt2-like protein mediates DNA methylation in Drosophila. Development 130:5083-5090

Lalande M, Calciano MA (2007) Molecular epigenetics of Angelman syndrome. Cell Mol Life Sci 64:947-960

Le Guezennec X, Vermeulen M, Brinkman AB, Hoeijmakers WA, Cohen A, Lasonder E, Stunnenberg HG (2006) MBD2/NuRD and MBD3/NuRD, two distinct complexes with different biochemical and functional properties. Mol Cell Biol 26:843-851

Li E, Bestor TH, Jaenisch R (1992) Targeted mutation of the DNA methyltransferase gene results in embryonic lethality. Cell 69:915-926

Liang G, Chan MF, Tomigahara Y, Tsai YC, Gonzales FA, Li E, Laird PW, Jones PA (2002) Cooperativity between DNA methyltransferases in the maintenance methylation of repetitive elements. Mol Cell Biol 22:480-491

Lopez-Serra L, Esteller M (2008) Proteins that bind methylated DNA and human cancer: reading the wrong words. $\mathrm{Br} \mathrm{J}$ Cancer 98:1881-1885

Luikenhuis S, Giacometti E, Beard CF, Jaenisch R (2004) Expression of $\mathrm{MeCP} 2$ in postmitotic neurons rescues Rett syndrome in mice. Proc Natl Acad Sci U S A 101:6033-6038

Lunyak VV, Burgess R, Prefontaine GG, Nelson C, Sze SH, Chenoweth J, Schwartz P, Pevzner PA, Glass C, Mandel G, Rosenfeld MG (2002) Corepressor-dependent silencing of chromosomal regions encoding neuronal genes. Science 298:17471752

Lunyak VV, Prefontaine GG, Rosenfeld MG (2004) REST and peace for the neuronal-specific transcriptional program. Ann N Y Acad Sci 1014:110-120

Lyko F, Ramsahoye BH, Jaenisch R (2000) DNA methylation in Drosophila melanogaster. Nature 408:538-540

Lyst MJ, Nan X, Stancheva I (2006) Regulation of MBD1-mediated transcriptional repression by SUMO and PIAS proteins. EMBO J 25:5317-5328 
MacKay AB, Mhanni AA, McGowan RA, Krone PH (2007) Immunological detection of changes in genomic DNA methylation during early zebrafish development. Genome 50:778-785

Macleod D, Clark VH, Bird A (1999) Absence of genome-wide changes in DNA methylation during development of the zebrafish. Nat Genet 23:139-140

Mann MR, Bartolomei MS (2002) Epigenetic reprogramming in the mammalian embryo: struggle of the clones. Genome Biol 3: reviews1003.1-1003.4

Marhold J, Brehm A, Kramer K (2004a) The Drosophila methyl-DNA binding protein MBD2/3 interacts with the NuRD complex via p55 and MI-2. BMC Mol Biol 5:20

Marhold J, Kramer K, Kremmer E, Lyko F (2004b) The Drosophila MBD2/3 protein mediates interactions between the MI-2 chromatin complex and CpT/A-methylated DNA. Development 131:6033-6039

Martens JH, O'Sullivan RJ, Braunschweig U, Opravil S, Radolf M, Steinlein P, Jenuwein T (2005) The profile of repeat-associated histone lysine methylation states in the mouse epigenome. EMBO J 24:800-812

Martin Caballero I, Hansen J, Leaford D, Pollard S, Hendrich BD (2009) The methyl-CpG binding proteins Mecp2, Mbd2 and Kaiso are dispensable for mouse embryogenesis, but play a redundant function in neural differentiation. PLoS ONE 4:e4315

Martinowich K, Hattori D, Wu H, Fouse S, He F, Hu Y, Fan G, Sun YE (2003) DNA methylation-related chromatin remodeling in activity-dependent BDNF gene regulation. Science 302:890893

Mayer W, Niveleau A, Walter J, Fundele R, Haaf T (2000) Demethylation of the zygotic paternal genome. Nature 403:501-502

McGowan RA, Martin CC (1997) DNA methylation and genome imprinting in the zebrafish, Danio rerio: some evolutionary ramifications. Biochem Cell Biol 75:499-506

Meehan RR (2003) DNA methylation in animal development. Semin Cell Dev Biol 14:53-65

Mello JA, Almouzni G (2001) The ins and outs of nucleosome assembly. Curr Opin Genet Dev 11:136-141

Mikkelsen TS, Ku M, Jaffe DB, Issac B, Lieberman E, Giannoukos G, Alvarez P, Brockman W, Kim TK, Koche RP, Lee W, Mendenhall E, O'Donovan A, Presser A, Russ C, Xie X, Meissner A, Wernig M, Jaenisch R, Nusbaum C, Lander ES, Bernstein BE (2007) Genome-wide maps of chromatin state in pluripotent and lineage-committed cells. Nature 448:553-560

Millar CB, Guy J, Sansom OJ, Selfridge J, MacDougall E, Hendrich B, Keightley PD, Bishop SM, Clarke AR, Bird A (2002) Enhanced $\mathrm{CpG}$ mutability and tumorigenesis in MBD4deficient mice. Science 297:403-405

Morgan HD, Santos F, Green K, Dean W, Reik W (2005) Epigenetic reprogramming in mammals. Hum Mol Genet 14(Spec No 1): R47-R58

Nakashima N, Yamagata T, Mori M, Kuwajima M, Suwa K, Momoi MY (2009) Expression analysis and mutation detection of DLX5 and DLX6 in autism. Brain Dev. doi:10.1016/j.braindev.2008.12.021

Nan X, Meehan RR, Bird A (1993) Dissection of the methyl-CpG binding domain from the chromosomal protein MeCP2. Nucleic Acids Res 21:4886-4892

Nan X, Ng HH, Johnson CA, Laherty CD, Turner BM, Eisenman RN, Bird A (1998) Transcriptional repression by the methyl-CpGbinding protein $\mathrm{MeCP} 2$ involves a histone deacetylase complex. Nature 393:386-389

Nan X, Hou J, Maclean A, Nasir J, Lafuente MJ, Shu X, Kriaucionis S, Bird A (2007) Interaction between chromatin proteins MECP2 and ATRX is disrupted by mutations that cause inherited mental retardation. Proc Natl Acad Sci U S A 104:2709-2714

$\mathrm{Ng} \mathrm{HH}$, Zhang Y, Hendrich B, Johnson CA, Turner BM, ErdjumentBromage H, Tempst P, Reinberg D, Bird A (1999) MBD2 is a transcriptional repressor belonging to the MeCP1 histone deacetylase complex. Nat Genet 23:58-61

Oda M, Yamagiwa A, Yamamoto S, Nakayama T, Tsumura A, Sasaki H, Nakao K, Li E, Okano M (2006) DNA methylation regulates long-range gene silencing of an X-linked homeobox gene cluster in a lineage-specific manner. Genes Dev 20:3382-3394

Ohki I, Shimotake N, Fujita N, Nakao M, Shirakawa M (1999) Solution structure of the methyl-CpG-binding domain of the methylationdependent transcriptional repressor MBD1. EMBO J 18:6653-6661

Okano M, Xie S, Li E (1998) Dnmt2 is not required for de novo and maintenance methylation of viral DNA in embryonic stem cells. Nucleic Acids Res 26:2536-2540

Okano M, Bell DW, Haber DA, Li E (1999) DNA methyltransferases Dnmt3a and Dnmt3b are essential for de novo methylation and mammalian development. Cell 99:247-257

Oswald J, Engemann S, Lane N, Mayer W, Olek A, Fundele R, Dean W, Reik W, Walter J (2000) Active demethylation of the paternal genome in the mouse zygote. Curr Biol 10:475-478

Palacios D, Puri PL (2006) The epigenetic network regulating muscle development and regeneration. J Cell Physiol 207:1-11

Patel CV, Gopinathan KP (1987) Determination of trace amounts of 5methylcytosine in DNA by reverse-phase high-performance liquid chromatography. Anal Biochem 164:164-169

Pradhan M, Esteve PO, Chin HG, Samaranayke M, Kim GD, Pradhan S (2008) CXXC domain of human DNMT1 is essential for enzymatic activity. Biochemistry 47:10000-10009

Pradhan S, Bacolla A, Wells RD, Roberts RJ (1999) Recombinant human DNA (cytosine-5) methyltransferase. I. Expression, purification, and comparison of de novo and maintenance methylation. J Biol Chem 274:33002-33010

Proffitt JH, Davie JR, Swinton D, Hattman S (1984) 5-Methylcytosine is not detectable in Saccharomyces cerevisiae DNA. Mol Cell Biol 4:985-988

Prokhortchouk A, Hendrich B, Jorgensen H, Ruzov A, Wilm M, Georgiev G, Bird A, Prokhortchouk E (2001) The p120 catenin partner Kaiso is a DNA methylation-dependent transcriptional repressor. Genes Dev 15:1613-1618

Prokhortchouk A, Sansom O, Selfridge J, Caballero IM, Salozhin S, Aithozhina D, Cerchietti L, Meng FG, Augenlicht LH, Mariadason JM, Hendrich B, Melnick A, Prokhortchouk E, Clarke A, Bird A (2006) Kaiso-deficient mice show resistance to intestinal cancer. Mol Cell Biol 26:199-208

Rai K, Chidester S, Zavala CV, Manos EJ, James SR, Karpf AR, Jones DA, Cairns BR (2007) Dnmt2 functions in the cytoplasm to promote liver, brain, and retina development in zebrafish. Genes Dev 21:261-266

Rai K, Huggins IJ, James SR, Karpf AR, Jones DA, Cairns BR (2008) DNA demethylation in zebrafish involves the coupling of a deaminase, a glycosylase, and gadd45. Cell 135:1201-1212

Rai K, Nadauld LD, Chidester S, Manos EJ, James SR, Karpf AR, Cairns BR, Jones DA (2006) Zebra fish Dnmt1 and Suv39h1 regulate organ-specific terminal differentiation during development. Mol Cell Biol 26:7077-7085

Rainier S, Johnson LA, Dobry CJ, Ping AJ, Grundy PE, Feinberg AP (1993) Relaxation of imprinted genes in human cancer. Nature 362:747-749

Reese BE, Bachman KE, Baylin SB, Rountree MR (2003) The methyl$\mathrm{CpG}$ binding protein MBD1 interacts with the p150 subunit of chromatin assembly factor 1 . Mol Cell Biol 23:3226-3236

Reik W, Dean W, Walter J (2001) Epigenetic reprogramming in mammalian development. Science 293:1089-1093

Riccio A, Aaltonen LA, Godwin AK, Loukola A, Percesepe A, Salovaara R, Masciullo V, Genuardi M, Paravatou-Petsotas M, Bassi DE, Ruggeri BA, Klein-Szanto AJ, Testa JR, Neri G, Bellacosa A (1999) The DNA repair gene MBD4 (MED1) is mutated in human carcinomas with microsatellite instability. Nat Genet 23:266-268 
Rietveld LE, Caldenhoven E, Stunnenberg HG (2002) In vivo repression of an erythroid-specific gene by distinct corepressor complexes. EMBO J 21:1389-1397

Robertson KD, Ait-Si-Ali S, Yokochi T, Wade PA, Jones PL, Wolffe AP (2000) DNMT1 forms a complex with Rb, E2F1 and HDAC1 and represses transcription from E2F-responsive promoters. Nat Genet 25:338-342

Roder K, Hung MS, Lee TL, Lin TY, Xiao H, Isobe KI, Juang JL, Shen CJ (2000) Transcriptional repression by Drosophila methylCpG-binding proteins. Mol Cell Biol 20:7401-7409

Rupp RA, Singhal N, Veenstra GJ (2002) When the embryonic genome flexes its muscles. Eur J Biochem 269:2294-2299

Ruzov A, Dunican DS, Prokhortchouk A, Pennings S, Stancheva I, Prokhortchouk E, Meehan RR (2004) Kaiso is a genome-wide repressor of transcription that is essential for amphibian development. Development 131:6185-6194

Ruzov A, Hackett JA, Prokhortchouk A, Reddington JP, Madej MJ, Dunican DS, Prokhortchouk E, Pennings S, Meehan RR (2009) The interaction of xKaiso with xTcf3: a revised model for integration of epigenetic and Wnt signalling pathways. Development 136:723-727

Saito M, Ishikawa F (2002) The mCpG-binding domain of human MBD3 does not bind to $\mathrm{mCpG}$ but interacts with $\mathrm{NuRD} / \mathrm{Mi} 2$ components HDAC1 and MTA2. J Biol Chem 277:35434 35439

Sansom OJ, Berger J, Bishop SM, Hendrich B, Bird A, Clarke AR (2003) Deficiency of Mbd2 suppresses intestinal tumorigenesis. Nat Genet 34:145-147

Sarraf SA, Stancheva I (2004) Methyl-CpG binding protein MBD1 couples histone $\mathrm{H} 3$ methylation at lysine 9 by SETDB1 to DNA replication and chromatin assembly. Mol Cell 15:595-605

Schmitz KM, Schmitt N, Hoffmann-Rohrer U, Schafer A, Grummt I, Mayer C (2009) TAF12 recruits Gadd45a and the nucleotide excision repair complex to the promoter of rRNA genes leading to active DNA demethylation. Mol Cell 33:344-353

Schmitzova J, Klaudiny J, Albert S, Schroder W, Schreckengost W, Hanes J, Judova J, Simuth J (1998) A family of major royal jelly proteins of the honeybee Apis mellifera L. Cell Mol Life Sci 54:1020-1030

Schule B, Li HH, Fisch-Kohl C, Purmann C, Francke U (2007) DLX5 and DLX6 expression is biallelic and not modulated by MeCP2 deficiency. Am J Hum Genet 81:492-506

Screaton RA, Kiessling S, Sansom OJ, Millar CB, Maddison K, Bird A, Clarke AR, Frisch SM (2003) Fas-associated death domain protein interacts with methyl-CpG binding domain protein 4: a potential link between genome surveillance and apoptosis. Proc Natl Acad Sci U S A 100:5211-5216

Selker EU, Tountas NA, Cross SH, Margolin BS, Murphy JG, Bird AP, Freitag M (2003) The methylated component of the Neurospora crassa genome. Nature 422:893-897

Shahbazian M, Young J, Yuva-Paylor L, Spencer C, Antalffy B, Noebels J, Armstrong D, Paylor R, Zoghbi H (2002) Mice with truncated $\mathrm{MeCP} 2$ recapitulate many Rett syndrome features and display hyperacetylation of histone H3. Neuron 35:243-254

Sharif J, Muto M, Takebayashi S, Suetake I, Iwamatsu A, Endo TA, Shinga J, Mizutani-Koseki Y, Toyoda T, Okamura K, Tajima S, Mitsuya K, Okano M, Koseki H (2007) The SRA protein Np95 mediates epigenetic inheritance by recruiting Dnmt1 to methylated DNA. Nature 450:908-912

Smart FM, Edelman GM, Vanderklish PW (2003) BDNF induces translocation of initiation factor $4 \mathrm{E}$ to mRNA granules: evidence for a role of synaptic microfilaments and integrins. Proc Natl Acad Sci U S A 100:14403-14408

Stancheva I, Meehan RR (2000) Transient depletion of xDnmt1 leads to premature gene activation in Xenopus embryos. Genes Dev $14: 313-327$
Stancheva I, Hensey C, Meehan RR (2001) Loss of the maintenance methyltransferase, xDnmt1, induces apoptosis in Xenopus embryos. EMBO J 20:1963-1973

Stancheva I, El-Maarri O, Walter J, Niveleau A, Meehan RR (2002) DNA methylation at promoter regions regulates the timing of gene activation in Xenopus laevis embryos. Dev Biol 243:155165

Stancheva I, Collins AL, Van den Veyver IB, Zoghbi H, Meehan RR (2003) A mutant form of MeCP2 protein associated with human Rett syndrome cannot be displaced from methylated DNA by notch in Xenopus embryos. Mol Cell 12:425-435

Tamaru H, Selker EU (2001) A histone H3 methyltransferase controls DNA methylation in Neurospora crassa. Nature 414:277-283

Tao J, Hu K, Chang Q, Wu H, Sherman NE, Martinowich K, Klose RJ, Schanen C, Jaenisch R, Wang W, Sun YE (2009) Phosphorylation of $\mathrm{MeCP} 2$ at Serine 80 regulates its chromatin association and neurological function. Proc Natl Acad Sci U S A 106:4882-4887

Tatematsu KI, Yamazaki T, Ishikawa F (2000) MBD2-MBD3 complex binds to hemi-methylated DNA and forms a complex containing DNMT1 at the replication foci in late S phase. Genes Cells 5:677-688

Traynor J, Agarwal P, Lazzeroni L, Francke U (2002) Gene expression patterns vary in clonal cell cultures from Rett syndrome females with eight different MECP2 mutations. BMC Med Genet 3:12

Tropea D, Giacometti E, Wilson NR, Beard C, McCurry C, Fu DD, Flannery R, Jaenisch R, Sur M (2009) Partial reversal of Rett Syndrome-like symptoms in MeCP2 mutant mice. Proc Natl Acad Sci U S A 106:2029-2034

Tudor M, Akbarian S, Chen RZ, Jaenisch R (2002) Transcriptional profiling of a mouse model for Rett syndrome reveals subtle transcriptional changes in the brain. Proc Natl Acad Sci U S A 99:15536-15541

Tweedie S, Charlton J, Clark V, Bird A (1997) Methylation of genomes and genes at the invertebrate-vertebrate boundary. Mol Cell Biol 17:1469-1475

Uno T, Nomura Y, Nakamura M, Nakao A, Tajima S, Kanamaru K, Yamagata H, Iwanaga Y (2005) Expression, purification and characterization of methyl DNA binding protein from Bombyx mori. J Insect Sci 5:8

Veenstra GJ, Wolffe AP (2001) Constitutive genomic methylation during embryonic development of Xenopus. Biochim Biophys Acta 1521:39-44

Villa R, Morey L, Raker VA, Buschbeck M, Gutierrez A, De Santis F, Corsaro M, Varas F, Bossi D, Minucci S, Pelicci PG, Di Croce L (2006) The methyl-CpG binding protein MBD1 is required for PML-RARalpha function. Proc Natl Acad Sci U S A 103:1400 1405

Wade PA (2001) Methyl CpG-binding proteins and transcriptional repression. Bioessays 23:1131-1137

Wade PA, Gegonne A, Jones PL, Ballestar E, Aubry F, Wolffe AP (1999) Mi-2 complex couples DNA methylation to chromatin remodelling and histone deacetylation. Nat Genet 23:62-66

Wagner S, Chiosea S, Nickerson JA (2003) The spatial targeting and nuclear matrix binding domains of SRm160. Proc Natl Acad Sci U S A 100:3269-3274

Wallace JA, Felsenfeld G (2007) We gather together: insulators and genome organization. Curr Opin Genet Dev 17:400-407

Wang Y, Jorda M, Jones PL, Maleszka R, Ling X, Robertson HM, Mizzen CA, Peinado MA, Robinson GE (2006) Functional CpG methylation system in a social insect. Science 314:645-647

Watanabe S, Ichimura T, Fujita N, Tsuruzoe S, Ohki I, Shirakawa M, Kawasuji M, Nakao M (2003) Methylated DNA-binding domain 1 and methylpurine-DNA glycosylase link transcriptional repression and DNA repair in chromatin. Proc Natl Acad Sci U S A 100:12859-12864 
Weber M, Davies JJ, Wittig D, Oakeley EJ, Haase M, Lam WL, Schubeler D (2005) Chromosome-wide and promoter-specific analyses identify sites of differential DNA methylation in normal and transformed human cells. Nat Genet 37:853-862

Weitzel JM, Buhrmester H, Stratling WH (1997) Chicken MARbinding protein ARBP is homologous to rat methyl-CpG-binding protein MeCP2. Mol Cell Biol 17:5656-5666

Weksberg R, Smith AC, Squire J, Sadowski P (2003) BeckwithWiedemann syndrome demonstrates a role for epigenetic control of normal development. Hum Mol Genet 12(Spec No 1):R61R68

Wilson GG, Murray NE (1991) Restriction and modification systems. Annu Rev Genet 25:585-627

Wolffe AP, Jones PL, Wade PA (1999) DNA demethylation. Proc Natl Acad Sci U S A 96:5894-5896

Wong E, Yang K, Kuraguchi M, Werling U, Avdievich E, Fan K, Fazzari M, Jin B, Brown AM, Lipkin M, Edelmann W (2002) Mbd4 inactivation increases Cright-arrowT transition mutations and promotes gastrointestinal tumor formation. Proc Natl Acad Sci U S A 99:14937-14942

Woo HR, Pontes O, Pikaard CS, Richards EJ (2007) VIM1, a methylcytosine-binding protein required for centromeric heterochromatinization. Genes Dev 21:267-277

Wood AJ, Oakey RJ (2006) Genomic imprinting in mammals: emerging themes and established theories. PLoS Genet 2:e147

Xu GL, Bestor TH, Bourc'his D, Hsieh CL, Tommerup N, Bugge M, Hulten M, Qu X, Russo JJ, Viegas-Pequignot E (1999) Chromosome instability and immunodeficiency syndrome caused by mutations in a DNA methyltransferase gene. Nature 402:187191

Yasui DH, Peddada S, Bieda MC, Vallero RO, Hogart A, Nagarajan RP, Thatcher KN, Farnham PJ, Lasalle JM (2007) Integrated epigenomic analyses of neuronal $\mathrm{MeCP} 2$ reveal a role for longrange interaction with active genes. Proc Natl Acad Sci U S A 104:19416-19421

Yoder JA, Walsh CP, Bestor TH (1997) Cytosine methylation and the ecology of intragenomic parasites. Trends Genet 13:335-340

Yoon HG, Chan DW, Reynolds AB, Qin J, Wong J (2003) N-CoR mediates DNA methylation-dependent repression through a methyl CpG binding protein Kaiso. Mol Cell 12:723-734

Young JI, Hong EP, Castle JC, Crespo-Barreto J, Bowman AB, Rose MF, Kang D, Richman R, Johnson JM, Berget S, Zoghbi HY (2005) Regulation of RNA splicing by the methylationdependent transcriptional repressor methyl-CpG binding protein 2. Proc Natl Acad Sci U S A 102:17551-17558

Zeev BB, Yaron Y, Schanen NC, Wolf H, Brandt N, Ginot N, Shomrat R, Orr-Urtreger A (2002) Rett syndrome: clinical manifestations in males with MECP2 mutations. J Child Neurol 17:20-24

Zeitlin S, Parent A, Silverstein S, Efstratiadis A (1987) Pre-mRNA splicing and the nuclear matrix. Mol Cell Biol 7:111-120

Zhang Y, Ng HH, Erdjument-Bromage H, Tempst P, Bird A, Reinberg D (1999) Analysis of the NuRD subunits reveals a histone deacetylase core complex and a connection with DNA methylation. Genes Dev 13:1924-1935

Zhao X, Ueba T, Christie BR, Barkho B, McConnell MJ, Nakashima K, Lein ES, Eadie BD, Willhoite AR, Muotri AR, Summers RG, Chun J, Lee KF, Gage FH (2003) Mice lacking methyl-CpG binding protein 1 have deficits in adult neurogenesis and hippocampal function. Proc Natl Acad Sci U S A 100:6777-6782

Zhou Z, Hong EJ, Cohen S, Zhao WN, Ho HY, Schmidt L, Chen WG, Lin Y, Savner E, Griffith EC, Hu L, Steen JA, Weitz CJ, Greenberg ME (2006) Brain-specific phosphorylation of MeCP2 regulates activity-dependent Bdnf transcription, dendritic growth, and spine maturation. Neuron 52:255-269 